US Army Corps

of Engineers ${ }_{\circledast}$

Engineer Research and

Development Center

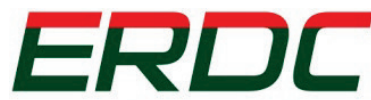

INNOVATIVE SOLUTIONS

for a safer, better world

Dredging Innovations Group

\title{
Methylmercury Screening Models for Surface Water Habitat Restoration: A Case Study in Duluth-Superior Harbor
}

Philip T. Gidley, Joseph P. Kreitinger, Mansour Zakikhani, November 2017

and Burton C. Suedel

\section{Before}

After

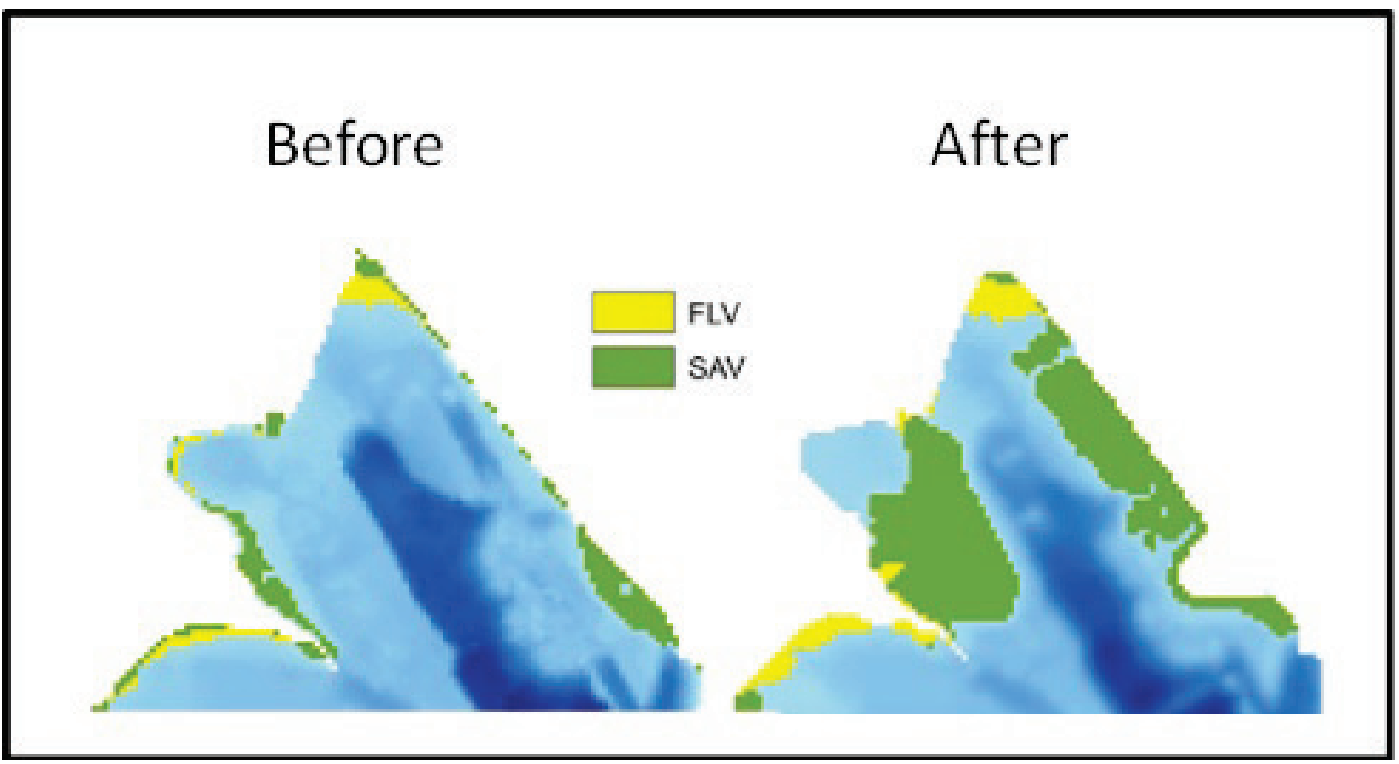


The U.S. Army Engineer Research and Development Center (ERDC) solves the nation's toughest engineering and environmental challenges. ERDC develops innovative solutions in civil and military engineering, geospatial sciences, water resources, and environmental sciences for the Army, the Department of Defense, civilian agencies, and our nation's public good. Find out more at www.erdc.usace.army.mil.

To search for other technical reports published by ERDC, visit the ERDC online library at http://acwc.sdp.sirsi.net/client/default. 


\section{Methylmercury Screening Models for Surface Water Habitat Restoration: A Case Study in Duluth-Superior Harbor}

Philip T. Gidley, Joseph P. Kreitinger, Mansour Zakikhani, and Burton C. Suedel

Environmental Laboratory

U.S. Army Engineer Research and Development Center

3909 Halls Ferry Road

Vicksburg, MS 39180-6199

Final report

Approved for public release; distribution is unlimited.

Prepared for Dredging Innovations Group and Engineering With Nature

U.S. Army Engineer Research and Development Center (ERDC)

Environmental Laboratory (EL)

3909 Halls Ferry Road Vicksburg, MS 39180-6199

Under Addressing Dredged Material Management-Related Challenges at DuluthSuperior Harbor. 


\section{Abstract}

The placement of dredged material for creating vegetated shallow water aquatic habitat is being assessed for changes in long-term bioavailability of mercury (Hg) to wildlife and humans. The three models used in this study (HERMES, WASP, and SERAFM) were applied in different ways to explore the possible strengths of each model, rather than to make direct comparisons between models. The HERMES model, which was most explicitly changed to account for aquatic plant growth, showed the greatest increases in sediment methylmercury ( $\mathrm{MeHg}$ ). The WASP model, which was most likely simulating a situation where dredged material is placed and aquatic plants do not grow, showed the least overall changes in surface water and sediment MeHg. The SERAFM model, which had the least "flushing" of the surface water in the restored scenario, showed the greatest increases in surface water $\mathrm{MeHg}$ (despite entered reductions in sediment $\mathrm{Hg}$ ). This study focused on the usefulness of each of the models separately for their ability to predict long-term MeHg changes in sediment, sediment porewater, surface water (including suspended particulates), and dissolved-in-surface water after the creation of shallow water habitat, relative to a "no-action" scenario at the site.

DISCLAIMER: The contents of this report are not to be used for advertising, publication, or promotional purposes. Citation of trade names does not constitute an official endorsement or approval of the use of such commercial products. All product names and trademarks cited are the property of their respective owners. The findings of this report are not to be construed as an official Department of the Army position unless so designated by other authorized documents. 


\section{Contents}

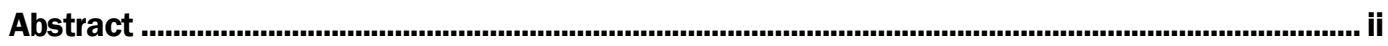

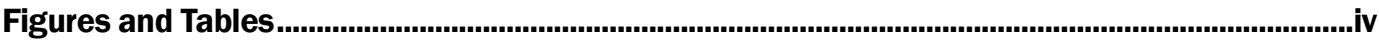

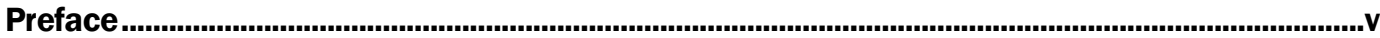

Executive Summary ................................................................................................................................vi

Acronyms ...............................................................................................................................................vii

Unit Conversion Factors .............................................................................................................

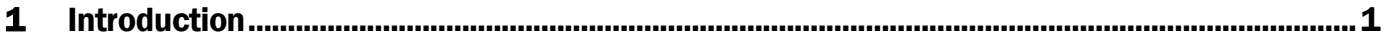

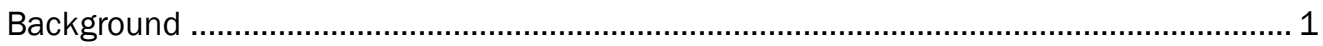

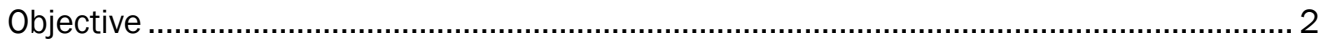

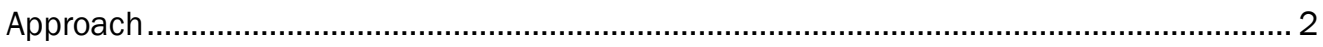

21st Avenue West Embayment .......................................................................................... 3

Western Lake Superior Sanitary District (WLSSD) ........................................................... 5

Miller and Coffee Creek ............................................................................................................ 7

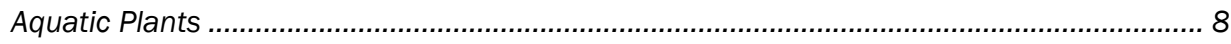

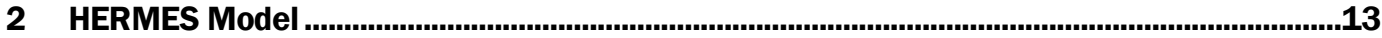

HERMES Results and Discussion ........................................................................ 15

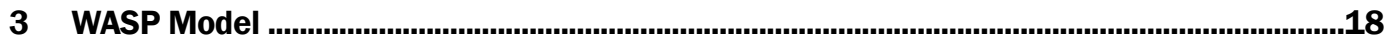

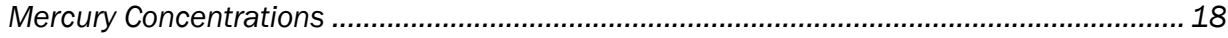

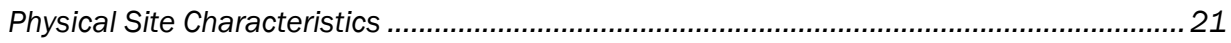

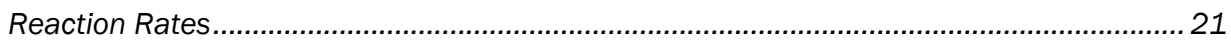

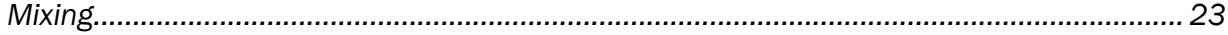

Flows

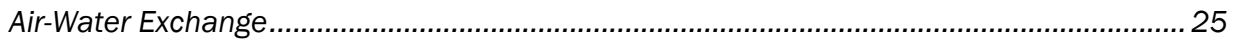

WASP Results and Discussion ......................................................................... 31

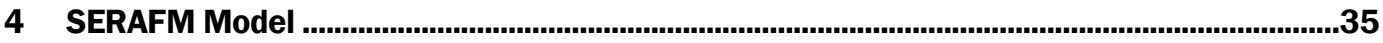

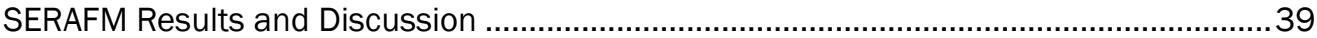

5 Summary...................................................................................................................................42

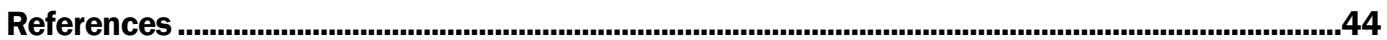

Report Documentation Page 


\section{Figures and Tables}

\section{Figures}

Figure 1. 21 $1^{\text {st }}$ Avenue West cove (the model domain). The yellow line marks the separation of the model domain and model boundary. Image from Google Earth.

Figure 2. Rendition of $21^{\text {st }}$ Ave before and after restoration. There will be an expected increase in submerged aquatic vegetation (SAV; green shading) and floating leaf vegetation (FLV; yellow shading) after implementation of the restoration design (images courtesy of Adam Wagner, Detroit District).

Figure 3. WASP conceptual model: A box model with four segments and surface water boundaries.

\section{Tables}

Table 1. Constant input parameters for the HERMES model...

Table 2. Varied HERMES input parameters for no-action scenario vs. restoration scenario.............14

Table 3. HERMES steady-state results: Mercury concentrations in surface water and sediment

Table 4. Inputs/initial conditions for the WASP box (4 segment) model.

Table 5. WASP input parameters that were altered between the "no-action" and "restoration" scenarios

Table 6. Ten-year WASP mercury model results with trend descriptions (over the later nine years). 32

Table 7. Constant input values for SERAFM - held constant for both scenarios...

Table 8. SERAFM inputs that were altered between no-action and restoration scenarios. .38

Table 9. SERAFM steady-state results: MeHg and total Hg concentrations in water and sediment

Table 10. Overall comparisons of MeHg concentrations between models. 


\section{Preface}

This study was originally developed to investigate risk due to mercury by predicting methylmercury concentrations in surface water and sediment. This study was jointly sponsored by the Dredging Innovations Group (DIG) and Engineering With Nature (EWN) under the project "Addressing Dredged Material Management-Related Challenges at Duluth-Superior Harbor.” Dr. Ned K. Mitchell was DIG Program Manager and EWN Program Manager was Dr. Todd S. Bridges (CEERD-EZS).

The findings and recommendations presented in this report are based upon research conducted at U.S. Army Engineer Research and Development Center (ERDC). The authors gratefully acknowledge Dr. Nathan W. Johnson and Dr. Paul R. Schroeder for helpful discussions and suggestions for some model input parameters.

This report was written under the direct supervision of Dr. Andy Martin, Chief, (CEERD-EPE); Dr. Bill Nelson, Chief, (CEERD-EPR); Mr. Warren Lorentz, Chief, Environmental Processes and Engineering Division, and Dr. Beth Fleming, Director, EL.

At the time of publication, COL Bryan S. Green was Commander of ERDC; Dr. David W. Pittman was Director of ERDC. 


\section{Executive Summary}

The placement of dredged material for creating vegetated shallow water aquatic habitat is being assessed for changes in long-term bioavailability of mercury (Hg) to wildlife and humans. The pathway of $\mathrm{Hg}$ to the human receptor is primarily through bioaccumulation of methylmercury $(\mathrm{MeHg})$ in fish. The bioaccumulation of MeHg in fish and other wildlife is related to the bioavailable $\mathrm{MeHg}$ in surface water and sediment. To study bioaccumulation and inform risk assessment, open-source, non-proprietary models were explored for predicting long-term changes in sediment and surface water $\mathrm{MeHg}$ concentrations in both solid and dissolved phases. The three models used in this study (HERMES, WASP, and SERAFM) were applied very differently. The models were applied in different ways to explore the possible strengths of each model, rather than to make direct comparisons between models. The HERMES model, which was most explicitly changed to account for the changes caused by aquatic plant growth, showed the greatest increases in sediment MeHg. The exact changes of $\mathrm{Hg}$ concentrations in the placed sediment were not directly inputted into the HERMES model. The WASP model, which was most likely simulating a situation where dredged material is placed and aquatic plants do not grow, showed the least overall changes in surface water and sediment $\mathrm{MeHg}$. It is possible that plants will not grow at the site. However, it may also be worthwhile to force more changes on the WASP model that would be caused by plant growth. WASP incorporated the most detail in terms of initial conditions at the site, and also has the potential to incorporate much more detail than was conducted here (i.e., WLSSD effluent, multiple boxes, temporal seasonal changes, plant evapotranspiration). The SERAFM model, which had the least "flushing" of the surface water in the restored scenario, showed the greatest increases in surface water $\mathrm{MeHg}$ (despite entered reductions in sediment $\mathrm{Hg}$ ). A proper comparison between these models would need to have identical exchange rates of the surface water set in all of the models. This study focused on the usefulness of each of the models separately for their ability to predict long-term $\mathrm{MeHg}$ changes in sediment, sediment porewater, surface water (including suspended particulates), and dissolved-in-surface water after the creation of shallow water habitat, relative to a "no-action" scenario at the site. The hydraulic residence time of the surface water may be a highly sensitive model parameter with a high degree of uncertainty (especially for the restoration scenario). Further work is necessary before these models can inform management decisions. This report begins to lay the groundwork for such an effort. 


\section{Acronyms}

$\begin{array}{ll}\text { Ave } & \text { Avenue } \\ \text { AOC } & \text { Area of Concern } \\ \text { CFU } & \text { Colony Forming Units } \\ \text { cm } & \text { centimeters } \\ \text { cms } & \text { cubic meters per second } \\ \text { C } & \text { Carbon } \\ \text { C/N } & \text { Carbon to Nitrogen } \\ \text { DIG } & \text { Dredging Innovations Group } \\ \text { DOC } & \text { Dissolved Organic Carbon } \\ \text { Eh } & \text { redox potential } \\ \text { EL } & \text { Environmental Laboratory } \\ \text { ERDC } & \text { Engineer Research and Development Center } \\ \text { EWN } & \text { Engineering With Nature } \\ \text { FLV } & \text { Floating Leaf Vegetation } \\ \text { ft } & \text { feet } \\ \text { ha } & \text { grams } \\ \text { GLWA } & \text { Great Lakes Water Quality Agreement } \\ \text { hectares }\end{array}$

HERMES Hg Environmental Ratios Multimedia Ecosystem Sources 


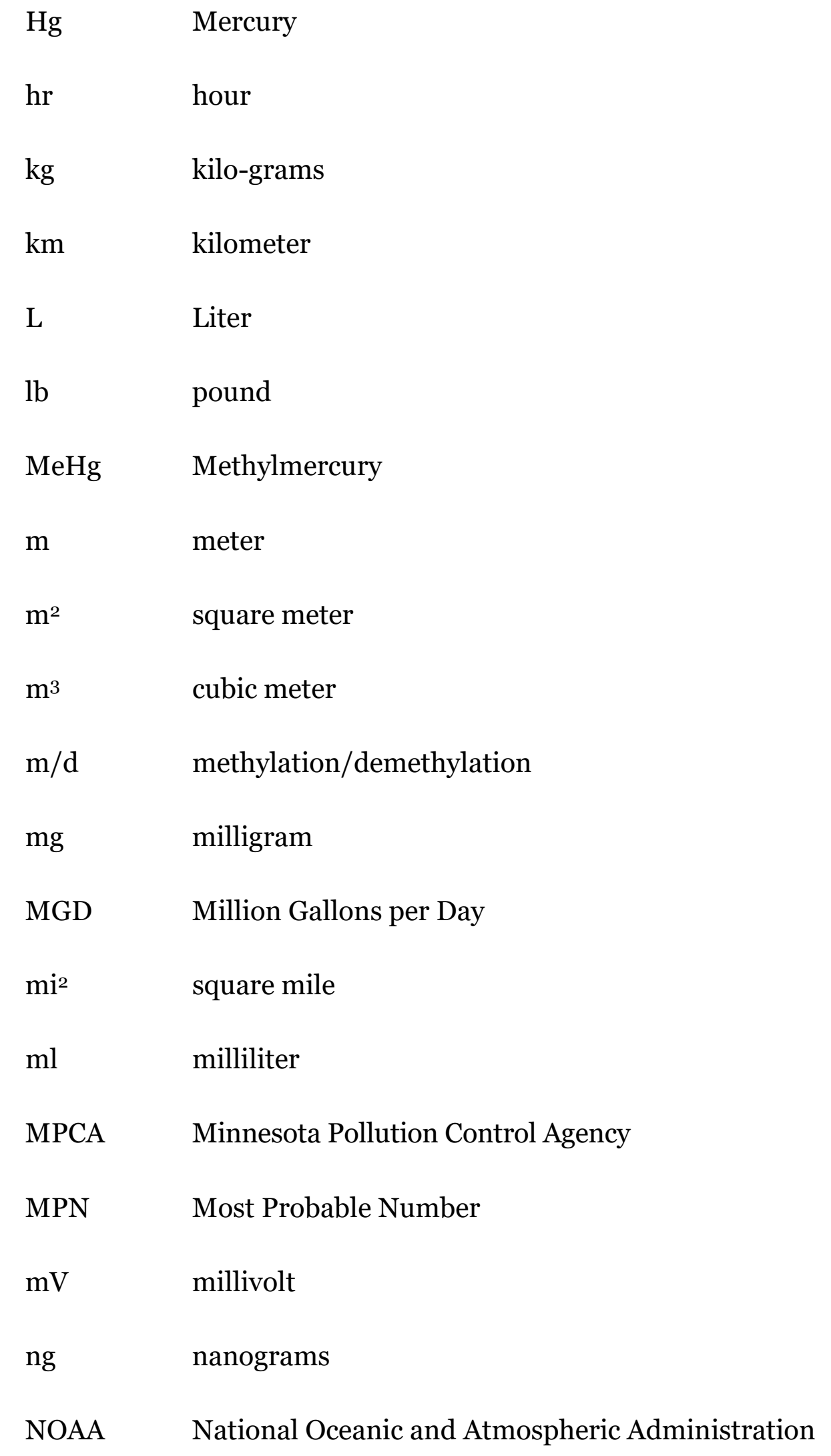




\begin{tabular}{ll} 
NTU & Nephelometric Turbidity Unit \\
P & Phosphorous \\
RCB & PolyChlorinated Biphenyl \\
RAP & Remediation Action Plan \\
sec & second \\
SAV & Submerged Aquatic Vegetation \\
SERAFM & Spreadsheet-based Ecological Risk Assessment for the Fate of \\
& Mercury \\
SLR & St. Louis River \\
THg & Total Mercury \\
TOC & Total Organic Carbon \\
TSS & Total Suspended Solids \\
USACE & U.S. Army Corps of Engineers \\
USEPA & U.S. Environmental Protection Agency \\
WASP & Water quality Analysis Simulation Program \\
WLSSD & Western Lake Superior Sanitary District \\
\hline micro-grams
\end{tabular}




\section{Unit Conversion Factors}

\begin{tabular}{|c|c|c|}
\hline Multiply & By & To Obtain \\
\hline acres & $4,046.873$ & square meters \\
\hline atmosphere (standard) & 101.325 & kilopascals \\
\hline bars & 100 & kilopascals \\
\hline cubic feet & 0.02831685 & cubic meters \\
\hline cubic inches & 1.6387064 E-05 & cubic meters \\
\hline cubic yards & 0.7645549 & cubic meters \\
\hline degrees Fahrenheit & $(F-32) / 1.8$ & degrees Celsius \\
\hline feet & 0.3048 & meters \\
\hline gallons (U.S. liquid) & 3.785412 E-03 & cubic meters \\
\hline hectares & $1.0 \mathrm{E}+04$ & square meters \\
\hline inches & 0.0254 & meters \\
\hline knots & 0.5144444 & meters per second \\
\hline microns & 1.0 E-06 & meters \\
\hline miles (nautical) & 1,852 & meters \\
\hline miles (U.S. statute) & $1,609.347$ & meters \\
\hline miles per hour & 0.44704 & meters per second \\
\hline ounces (mass) & 0.02834952 & kilograms \\
\hline ounces (U.S. fluid) & 2.957353 E-05 & cubic meters \\
\hline pints (U.S. liquid) & $4.73176 \mathrm{E}-04$ & cubic meters \\
\hline pints (U.S. liquid) & 0.473176 & liters \\
\hline pounds (mass) & 0.45359237 & kilograms \\
\hline quarts (U.S. liquid) & 9.463529 E-04 & cubic meters \\
\hline yards & 0.9144 & meters \\
\hline
\end{tabular}




\section{Introduction}

\section{Background}

The bioaccumulation of mercury $(\mathrm{Hg})$ by fish in the Great Lakes is an environmental concern potentially impacting the management of dredged material from navigation projects. The U.S. Army Corps of Engineers (USACE) Detroit District is restoring shallow water aquatic habitat within Duluth-Superior Harbor using dredged materials obtained during maintenance of the federal navigation channel in the harbor. The USACE Detroit District is restoring shoreline habitat in the Duluth/Superior Harbor Great Lakes Area of Concern (AOC) that includes the beneficial use of navigation channel dredged material. The objective of the restoration project is to identify and develop low-cost, shallow-water dredged material placement methods, utilizing both engineered and natural processes, consistent with USACE Engineering With Nature principles (https://ewn.el.erdc.dren.mil/index.html).

The beneficial use of dredged material as performed in Duluth-Superior Harbor is consistent with EWN, a U.S. Army Corps of Engineers (USACE) initiative enabling more sustainable delivery of economic, social, and environmental benefits associated with water resources projects. EWN concepts addressed through this project include (1) the use of science and engineering to produce operational efficiencies supporting sustainable delivery of project benefits and (2) the use of natural processes to maximum benefit, thereby reducing demands on limited resources, minimizing the environmental footprint of projects, and enhancing the quality of project benefits. Finding cost-effective approaches for material handling that restore the desired habitat is critical for developing future shoreline habitat restoration projects in the Great Lakes.

The fate and transport of $\mathrm{Hg}$ in the freshwater aquatic environment is highly complex. Mercury enters the environment in the ionic form via atmospheric deposition or other - often historical - discharges. Transport processes occur because $\mathrm{Hg}$ is hydrophobic and associates with particulate matter and dissolved organic carbon (DOC). Thus, sediments are often storage (providing ongoing sources and sinks to surface water) for historical discharges of $\mathrm{Hg}$. Methylation of $\mathrm{Hg}$ occurs by bacteria (primarily in the sediments) as they utilize labile organic carbon as an energy source, and 
often sulfate as a terminal electron acceptor. Trophic transfer of MeHg can then occur in the benthic and pelagic food webs. Empirical observations, from data collection, may be helpful for evaluating such complex systems. For example, a site can be monitored to understand changes in $\mathrm{Hg}$ concentrations in various compartments, such as sediment, surface water, and biota. Measured data are also required to ensure regulatory compliance. These guidelines can be different, depending on the agency that developed them. For example, all fish tissue samples from the embayment exceeded Canadian Hg guidelines, but were below Great Lakes Water Quality Agreement (GLWQA) guidelines (Host et al. 2013). In 2008, the Minnesota Pollution Control Agency (MPCA) adopted a fish-tissue mercury standard of $200 \mathrm{ng} / \mathrm{g}$ total, in edible fish tissue (MPCA 2010). The water and sediment guidelines for $\mathrm{Hg}$ are $1.3 \mathrm{ng} / \mathrm{L}$ in the surface water (MPCA 2010); and 180 $\mathrm{ng} / \mathrm{g}$ dry wt. (sediment quality target level 1 for high protection) or 1100 $\mathrm{ng} / \mathrm{g}$ dry wt. (sediment quality target level 2 for moderate protection) in the bulk sediments (USEPA 2000).

\section{Objective}

The objectives of this work were to develop a "how-to" for implementing mathematical models for the eventual purpose of predicting long-term $\mathrm{MeHg}$ changes in sediment, sediment porewater, surface water (including suspended particulates), and dissolved-in-surface water after the creation of shallow water habitat, relative to a "no-action" scenario at the site.

\section{Approach}

Collected $\mathrm{Hg}$ data can be used to develop site-specific fish-mercury bioaccumulation factors (Eikenberry et al. 2015). However, all empirical evidence is limited to the present time and conditions (future predictions are limited). In the case of aquatic habitat restoration sites, empirical evidence can be gathered from other locations in a system (in this case, the St. Louis River estuary), where vegetated, shallow-water habitat already exists. Present empirical evidence from vegetated locations may be used to indicate the future for the $21^{\text {st }}$ Ave. West cove (hereafter, simply referred to as "the cove" or "the site"). There are two limitations to this approach. First, the $21^{\text {st }}$ Ave. West Embayment (hereafter, referred to as " $21^{\text {st }}$ Ave.") is the location of the Western Lake Superior Sanitary District (WLSSD) wastewater treatment plant discharge. This is a significant historic source of $\mathrm{Hg}$ to the estuary (Glass et al. 1990). The wastewater treatment plant outfall also alters the cove chemically and physically, that - in turn - influences mercury fate and transport. Therefore, the outcome at $21^{\text {st }}$ Ave. may be quite 
different than other vegetated, shallow-water areas of the estuary. Second, empirical evidence of $\mathrm{Hg}$ alone does not describe the mechanisms behind changes in $\mathrm{Hg}$ fate and transport. A mechanistic understanding of change is helpful to evaluate possible operational and engineering controls to reduce $\mathrm{Hg}$ bioaccumulation. For example, future restorations could use amendments added to the dredged material during placement, such as activated carbon (Gilmour et al. 2013). Therefore, it is helpful to utilize existing mathematical models, designed for $\mathrm{Hg}$, to assess the multiple potential processes occurring in the cove that affect $\mathrm{Hg}$ fate and transport. Three models were investigated for understanding $\mathrm{Hg}$ in surface water and sediments: the Hg Environmental Ratios Multimedia Ecosystem Sources (HERMES) model (Ethier et al. 2010); the Water quality Analysis Simulation Program (WASP 7.3) with the Hg module (Wool et al. 2001); and the Spreadsheet-based Ecological Risk Assessment for the Fate of Mercury (SERAFM) model (Knightes 2008). Both WASP and SERAFM are U.S. Environmental Protection Agency (USEPA) models.

\section{1st Avenue West Embayment}

The lower 21 miles of the St. Louis River make up a 4856 ha estuary that contains a 213 ha project area known as $21^{\text {st }}$ Ave. (Host et al. 2013). This modeling effort focused on a portion of $21^{\text {st }}$ Ave. (the "cove" or "model domain") that is being designed to support submerged and emergent aquatic vegetation following restoration efforts (Figures 1 and 2).

Before dredged material placement took place, the deepest point at $21^{\text {st }}$ Ave. was 11 meters below the water surface (Host et al. 2013), which was the location of a deauthorized shipping channel. Offshore of the embayment (not shown in Figure 1) is Interstate Island, which is home to common terns and ring-billed gulls. Other birds at $21^{\text {st }}$ Ave. include herring gulls, American crows, European starlings, house sparrows, rock pigeons (Host et al. 2013), mallard ducks, common mergansers, double crested cormorants, and rock doves (Hansen et al. 2011). Ducks are known to feed on aquatic plants (Lacoul and Freedman 2006), and other sources of herbivory are discussed later. The 21st Ave. site was sampled by Host et al. in late summer of 2011 until the fall of 2012. A "500-year recurrence interval flood" occurred in the St. Louis River in June 2012 (Angradi et al. 2013). Much of the site data for $21^{\text {st }}$ Ave. is from shortly before, or shortly after, this major flood. Dredged material placement began in 2013. This makes the establishment of baseline conditions at this site difficult. Data from this period need to be considered with the knowledge of the unusual flood event. 
Figure 1. 21 $1^{\text {st }}$ Avenue West cove (the model domain). The yellow line marks the separation of the model domain and model boundary. Image from Google Earth.

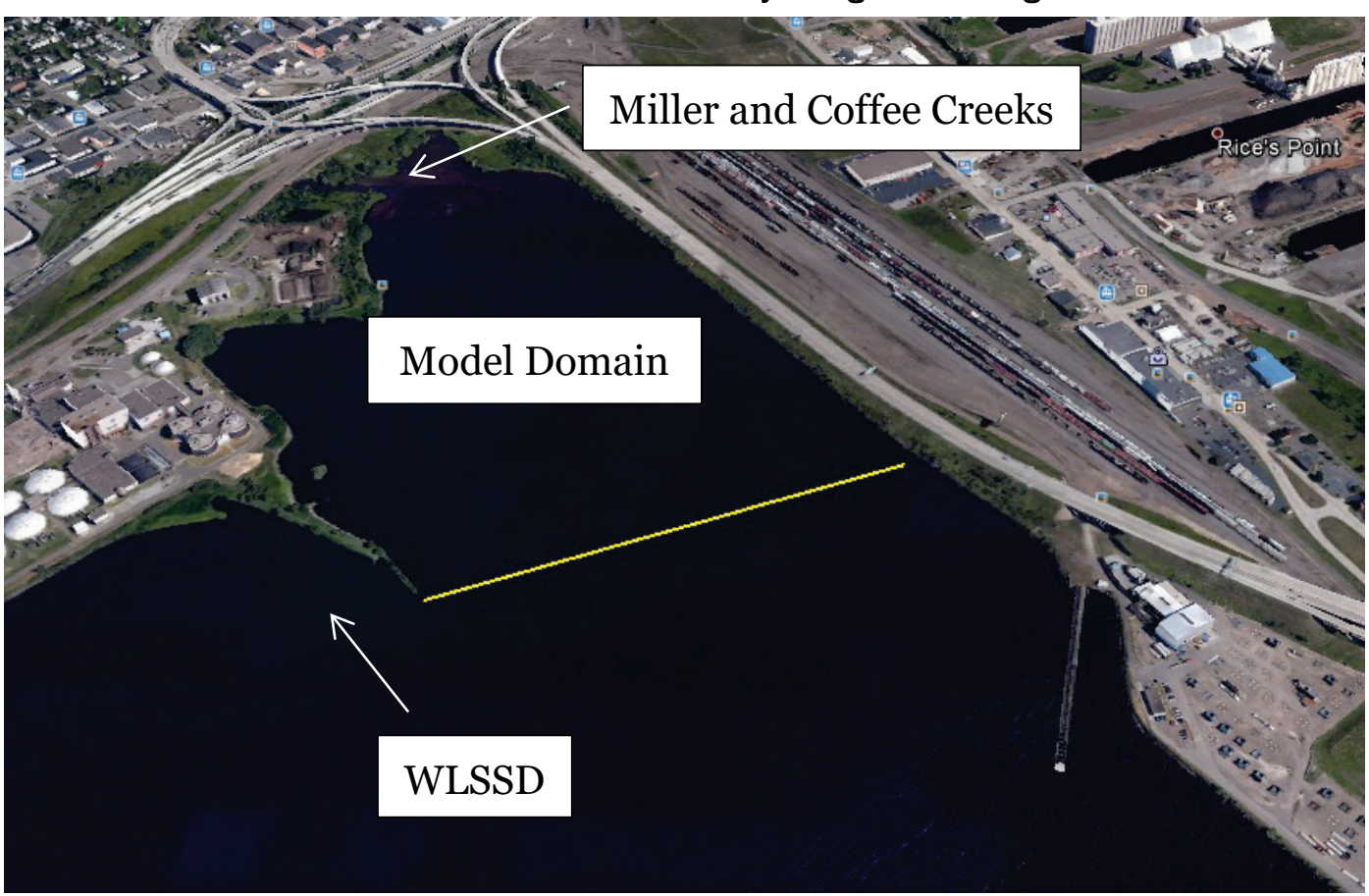

Before dredged material placement, vegetation at $21^{\text {st }}$ Ave. was sparse and variable (Host et al. 2013). Approximately $60 \%$ of 51 sampling points $(<2$ meters depth) had submerged aquatic vegetation (SAV) (Host et al. 2013). The most common SAV was Vallisneria americana Michx. (American wild celery) at 30\%, and filamentous algae at $16 \%$ (Host et al. 2013). Secchi depths were at approximately 0.63 meters (Host et al. 2013). Submerged aquatic plants will grow in water depths that are up to 2-3 times the Secchi depth (Lacoul and Freedman 2006). Alkalinity, total phosphorous (P), color, and turbidity were measured to be $81.9 \mathrm{mg} / \mathrm{L} \mathrm{CaCO} 3,74 \mu \mathrm{g} / \mathrm{L}, 232$ pt-co, and 7.6 Nephelometric Turbidity Units (NTUs), respectively (Host et al. 2012). The total $P$ in the estuary has been measured by Angradi et al. (2013) to be closer to $40 \mu \mathrm{g} / \mathrm{L}$. Approximately $40 \%$ of the shallow areas that seem favorable for aquatic vegetation had no floating leaf or emergent vegetation (only SAV and algae) (Host et al. 2013). Bird herbivory was the suspected cause for this lack of vegetation, as vegetation grew well in bird exclosures (Host et al. 2013; Moore et al. 2010). Along Garfield Street, $V$. americana and filamentous algae were again found, and the waterweed $E$. canadensis was located (Host et al. 2013). Taconite, iron formation, pellets were discovered along Garfield Street (Host et al. 2013). Wind fetch was used as a surrogate for wave energy, and was found to range from 56 to 1400 meters (Host et al. 2013). Initially, only $12 \%$ of $21^{\text {st }}$ Ave. was less than 
0.65 meters deep (Host et al. 2013). After dredged material placement, the overall depth of the cove will be reduced, which will allow for the possibility of macrophyte growth, but also increases the susceptibility of the sediment surface to erosion by wind-generated waves.

\section{Western Lake Superior Sanitary District (WLSSD)}

The WLSSD plant (discharge located at the 21 $1^{\text {st }}$ Ave.) uses a treatment process consisting of bar screens, grit removal, high-purity oxygen-activated sludge, mixed media filters (anthracite coal, silica sand, and garnet) and sodium hypochlorite treatment (LaPara et al. 2011). It services a population up 100,000 people, and the pulp and paper industry (Hensley 2012; Martinovic et al. 2008). The WLSSD's total effluent flow rate averages about 43 million gallons per day (MGD) (Host et al. 2013). The total effluent $\mathrm{Hg}$ concentrations have generally ranged between 2.0 and $3.5 \mathrm{ng} / \mathrm{L}$, and the total filtered effluent has ranged between 1.3 and $1.8 \mathrm{ng} / \mathrm{L}$ since $2009^{1}$ This exceeds $\mathrm{Hg}$ guidelines of $1.3 \mathrm{ng} / \mathrm{L}$ (MPCA 2010), but dilution in the bay is quickly achieved. Historically, the WLSSD discharge has been a much larger source of mercury to the estuary. A study in November 1987 to December 1988 measured the $\mathrm{Hg}$ in the effluent to be between 250 and $465 \mathrm{ng} / \mathrm{L}$, when a local incinerator was operating and discharged into the wastewater stream. Even when the incinerator was shut down, the WLSSD effluent Hg concentrations were $110 \mathrm{ng} / \mathrm{L}$ (Glass et al. 1990). Glass et al. (1990) estimated that nearly $70 \%$ of the $\mathrm{Hg}$ in the entire estuary, at that time, originated from the WLSSD effluent at $21^{\text {st }}$ Ave.

The WLSSD effluent also receives high doses of sodium hypochlorite (150$3101 \mathrm{lb} /$ day) periodically, when fecal coliform analysis at the WLSSD intake exceeds 100 most probable number (MPN)/100 ml (Hensley 2012). Sodium hypochlorite may also be added to the WLSSD effluent if a fiveday geo mean of 200 colony-forming units (CFU)/100 $\mathrm{ml}$ fecal coliforms is exceeded at Blatnick Bridge (Hansen et al. 2011). The WLSSD effluent fluctuates in turbidity from 1.5 to 30.8 NTUs (Eichmiller et al. 2013) and was reported to have $5 \mathrm{mg} / \mathrm{L}$ total suspended solids (TSS) (Martinovic et al. 2008). The WLSSD plant contributes to the surface water at 21 ${ }^{\text {st }}$ Ave. along with the St. Louis River, and Miller and Coffee Creeks. The portion of water from the WLSSD effluent could be as high as $1 / 5^{\text {th }}$ (immediate $5^{-}$ time dilution reported by Davis et al. 2013) of the mixing water into the $21^{\text {st }}$ Ave. cove from the estuary. About half of the inflow to the WLSSD

\footnotetext{
1 Dr. Nathan Johnson, University of Minnesota-Duluth, email communication, June 2015.
} 
plant is industrial (pulp and paper mills) and the other half is municipal (proportions fluctuate on a daily basis between 12-26\%) (Martinovic et al. 2008). Pulp and paper mill wastewaters are often sources of complex mixtures of chemicals, such as phytosterols, pulping compounds (dimethyl disulfide) and byproducts related to secondary biotreatment in the WLSSD plant (Davis et al. 2013). The effluent contains naturally occurring phytoestrogens from the paper mills, and synthetic estrogens of anthropogenic origin (Martinovic et al. 2008). During a shutdown of the pulp and paper mill ( $44 \%$ of inflow reduced to $4 \%$ of inflow to the WLSSD), a metabolomics study was conducted at the outfall with fathead minnows (Davis et al. 2013). Davis et al. (2013) showed that changes in polar hepatic endogenous metabolites in male fathead minnows were caused by the cumulative effects of chemicals in the pulp and paper mill wastewaters. Triclosan is also released at a rate of 5.2 to $8.7 \mathrm{~kg} /$ year from the outfall (Hensley et al. 2012). Given the level of influence the WLSSD has at $21^{\text {st }}$ Ave., it is important to put restoration goals in the proper perspective. There are certainly ongoing inputs of various constituents to the embayment.

The highest concentrations of mercury and polychlorinated biphenyls (PCBs) in the sediments at $21^{\text {st }}$ Ave. were found near the WLSSD outfall. Few oligochaetes could survive, and low survival of amphipods and reduced growth of midges were observed in toxicity tests with sediment collected near the outfall (Host et al. 2013). Historical Hg contamination from the WLSSD outfall resulted in sediment concentrations as high as $5070 \mathrm{ng} / \mathrm{g}$ in a 1987-1988 study (Glass et al. 1990). Richards et al. (1992) found that surface water temperatures and conductivities can be influenced by the WLSSD up to $0.5 \mathrm{~km}$ from the outfall. Temperature is the strongest statistical contributor to the variation in the distribution of aquatic plant species (Lacoul and Freedman 2006). Due to the temperature changes alone, $21^{\text {st }}$ Ave should not be expected to follow patterns observed in other parts of the St. Louis River estuary. During the winter, the outfall can attract certain species of fish, and might repel other species (Richards et al. 1992). The fish species most commonly found near the effluent were Northern pike, black bullhead, white sucker, and European ruffe (Richards et al. 1992). Species that were also caught near the outfall were carp, yellow perch, smallmouth bass and black crappie; while walleye, burbot, and lake trout were not caught in the mixing zone of the WLSSD effluent (Richards et al. 1992). Furthermore, carp are known to feed on aquatic plants (Lacoul and Freedman 2006). Only near the 
WLSSD outfall were the waterweed Elodea nuttallii and narrow-leaved Potamogeton sp. discovered, while some $V$. americana and filamentous algae were found near the WLSSD and in other locations in the cove. Canadian geese were also found near the WLSSD outfall (Host et al. 2013). Geese are also known to feed on aquatic plants (Lacoul and Freedman 2006). Plants and animals are influenced by the increased water temperatures near the outfall, which can be as high as $23^{\circ} \mathrm{C}$ in November (Richards et al. 1992). Davis et al. (2013) measured the WLSSD effluent to be in the range of 12 to $19^{\circ} \mathrm{C}$ (10 meters from discharge in April 2012), while Kahl et.al. (2014) measured temperatures 5-10 meters from the outfall to be $25^{\circ} \mathrm{C}$, and $20^{\circ} \mathrm{C}$ at $200-250$ meters from the outfall (all in September of 2010). Because of currents in the river, the outfall plume can shift rapidly. In the winter, spatial variations in water temperature can range over $19^{\circ} \mathrm{C}$ (Richards et al. 1992). The mean total alkalinity and hardness near the outfall were measured to be 158 and $159 \mathrm{mg} / \mathrm{L} \mathrm{CaCO}_{3}$ respectively, and decrease to 81 and $90 \mathrm{mg} / \mathrm{L} \mathrm{CaCO} 3$ at 200 meters from the outfall (Kahl et al. 2014).

The WLSSD outfall has a significant impact on the ecology around $21^{\text {st }}$ Ave. Aside from being a historical source of $\mathrm{Hg}$, it has many indirect impacts on $\mathrm{Hg}$. The elevated temperatures change the type of fish and the feeding patterns of those fish, which - in turn - will influence Hg uptake by fish in the cove. Knowledge of "home ranges" of different fish species may need to be treated differently in this area, compared to other locations in the estuary. The temperature, chlorine, and various chemicals in the effluent can have a significant impact on the type of aquatic plants that establish in an area. As stated before, $21^{\text {st }}$ Ave. should not be expected to follow the patterns of other areas in the estuary. Invasive species of plants and animals may be attracted to the outfall, thus influencing the restoration efforts. Finally, the geochemical patterns of $\mathrm{MeHg}$ formation that are found in the St. Louis River may not be true at $21^{\text {st }}$ Ave. For example, the $\mathrm{MeHg}$ to total $\mathrm{Hg}$ ratios in this area may always be different compared to other areas in the estuary with otherwise similar density of vegetation and hydraulic mixing.

\section{Miller and Coffee Creek}

Miller and Coffee Creeks flow into the cove at 21st Ave. after running underground in downtown Duluth (Fitspatrick 2006). Miller Creek is substantially larger than Coffee Creek (9.3 $\mathrm{mi}^{2}$ watershed vs $1.6 \mathrm{~m}^{2}$ watershed). The Coffee Creek watershed is approximately $66 \%$ developed 
(urban), 8\% upland forest, 20\% lowland forest, and 4\% lowland shrubs, while the Miller Creek watershed is approximately $60 \%$ developed, $3 \%$ upland forest, $21 \%$ lowland forests, $6 \%$ upland shrubs and $8 \%$ lowland shrubs (Fitspatrick 2006). The streams have seasonal high flow, coincident with snowmelt and spring rains. The creeks also carry trace metals, road salt, sediment, and nutrients into the cove. Estimation methods for $\mathrm{Hg}$ inputs from the creeks are presented later. There are stormwater detention ponds at various points within each creek watershed. The soil type in the Miller Creek watershed is coarse-textured acidic glacial till (red sandy loam) (Anderson et al. 2000). The flow rate generally ranges from 0.1-1.4 cubic meters per second ( $\mathrm{m} 3 / \mathrm{s}$ ) with $<1$ to 12 $\mathrm{mg} / \mathrm{L}$ TSS ( $\max 50 \mathrm{mg} / \mathrm{L}$ TSS) (Anderson et al. 2000). Others have reported a median flow of $0.26 \mathrm{~m}^{3} / \mathrm{s}$ with a maximum of $8.2 \mathrm{~m} 3 / \mathrm{s}$ (Erickson et al. 2010) (This compares with $0.001 \mathrm{~m} 3 / \mathrm{s}(\sim 5000 \mathrm{mg} / \mathrm{L} \mathrm{TSS})$ from the temporary hydraulic placement of dredged material, and $1.7 \mathrm{~m} 3 / \mathrm{s}$ ( 5 to $21 \mathrm{mg} / \mathrm{L} \mathrm{TSS}$ ) from the wastewater outfall). The salt content (chloride) in Miller Creek can reach $1400 \mathrm{mg} / \mathrm{L}$ with typical base flow levels of about $100 \mathrm{mg} / \mathrm{L}$ (Anderson et al. 2000). The salinity threshold for many freshwater aquatic plants is $10,000 \mathrm{mg} / \mathrm{L}$ (Lacoul and Freedman 2006). Therefore, salt inputs from the creeks should not adversely affect aquatic plants in the cove. Miller Creek is typical of Duluth area streams, having low gradient headwaters with wetlands and shrub lands, and then descending across exposed bedrock (Fitspatrick 2006; Erickson 2010). There is little impact of groundwater on the creek. Most of the baseflow is dependent on rainfall, snowmelt, and storage in the headwater wetlands (Erickson 2010). In conclusion, the creeks that flow into the cove will have a varying level of influence on $\mathrm{Hg}$ fate and transport, depending on the season and the maturity of the restoration effort (e.g., aquatic plant growth and hydraulic mixing).

\section{Aquatic Plants}

Successful restoration at $21^{\text {st }}$ Ave. relies on the colonization and establishment of aquatic plants. A rendition of $21^{\text {st }}$ Ave. before and after restoration is provided in Figure 2. The cove will achieve shallow water depths after restoration designed to increase coverage of both SAV and floating leaf vegetation (FLV). The native $V$. americana is a likely species of SAV to colonize the area (Angradi et al. 2013; Host et al. 2012, 2013). Angradi et al. (2013) found that in St. Louis Bay, where the water depth is less than $1.5 \mathrm{~m}, V$. americana should grow. In more sheltered areas, a mixture of SAV, floating vegetation, and emergent vegetation should grow 
(Angradi et al. 2013). However, increasing wave height can cause significant damage to $V$. americana (Madsen et al. 2001), and $21^{\text {st }}$ Ave. is exposed to wave action sufficient to impact this species. The flood (occurring in June 2012) also adversely affected SAV in the St. Louis River estuary (Angradi et al. 2013), and the length of time for recovery of turbidity levels from flood conditions are unknown. This could cause deviation from patterns observed by Angradi et al (2013) prior to the 2012 flood. The modeling effort conducted herein explored two scenarios: "noaction," and dredged material placement with the possible growth of aquatic plants ("restoration").

Figure 2. Rendition of $21^{\text {st }}$ Ave before and after restoration. There will be an expected increase in submerged aquatic vegetation (SAV; green shading) and floating leaf vegetation (FLV; yellow shading) after implementation of the restoration design (images courtesy of Adam Wagner, Detroit District).

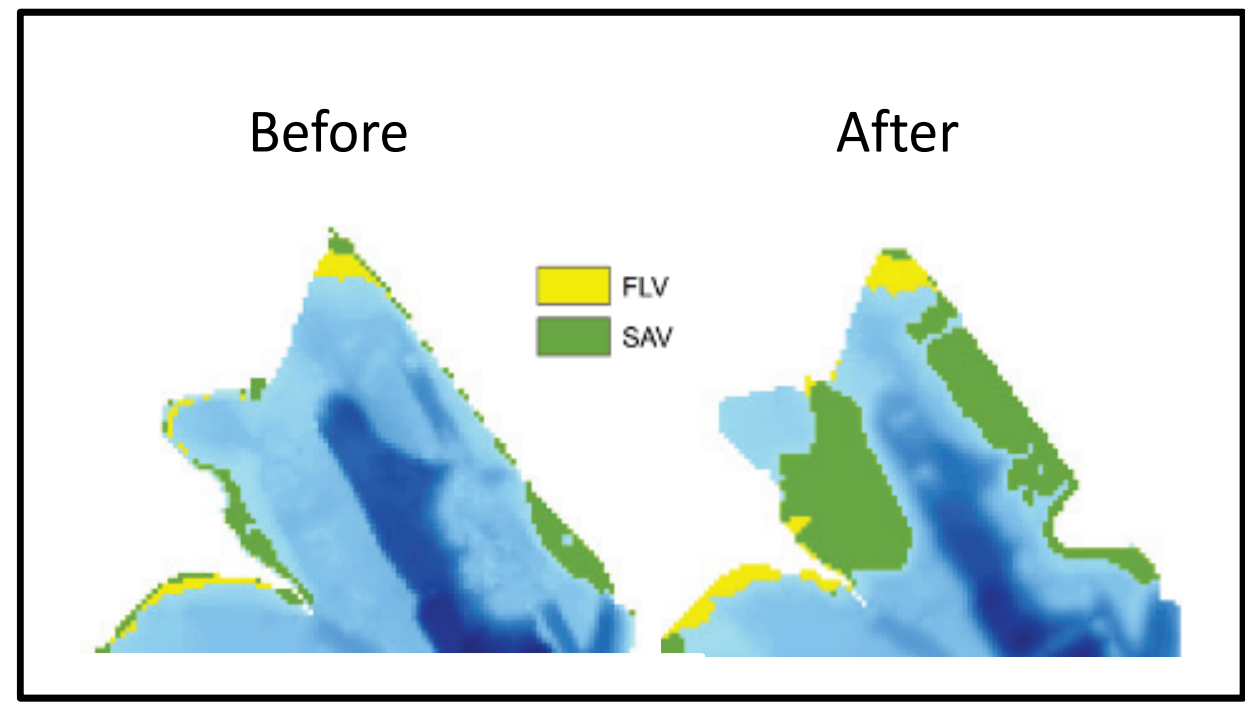

Near the WLSSD outfall, the native waterweed Elodea nuttallii and narrow-leaved Potamogeton sp. (both SAV) were found in addition to $V$. americana (Host et al. 2013). The WLSSD outfall is a source of warm water year-round, with periods of chlorination. Studies have found that total chlorine residuals of just $0.05 \mathrm{mg} / \mathrm{L}$ can depress shoot and total aquatic vegetation dry wt. by 30\% (Watkins and Hammerschlag 1984). Intermittent exposure of vegetation to chlorine at levels less than $1 \mathrm{mg} / \mathrm{L}$ showed no effect on aquatic plants (Watkins and Hammerschlag 1984). The WLSSD effluent is in the range of 0.3 to $6 \mathrm{mg} / \mathrm{L}$ chlorine (when it is used). A factor-of- 5 dilution is quickly attained in the embayment (Davis et al. 2013), which bring concentrations of $6 \mathrm{mg} / \mathrm{L}$ down to $1 \mathrm{mg} / \mathrm{L}$. Therefore, the chlorination of the WLSSD effluent should not adversely 
affect aquatic plant growth in the cove. In studies of the SAV, Elodea canadensis, greater standing crops can exist in the thermal mixing zone of effluents (Haag and Gorham 1977). During winter months, the lack of ice cover near thermal effluents also leads to more light penetration and earlier spring productivity (Haag and Gorham 1977). The presence of the WLSSD at $21^{\text {st }}$ Ave. may increase the likelihood of aquatic plant growth in the area relative to other sites. This increased likelihood of plant growth includes possible invasive species, and must also consider the increased possibility of herbivory (by birds and certain species of fish). Invasive aquatic plants that currently exist in the St. Louis River include purple loosestrife, Myriophyllum spicatum (Eurasian watermilfoil)2 ${ }^{2}$ and Phragmites.

Aquatic plants influence $\mathrm{Hg}$ fate, transport, and bioavailability directly (Cosio et al. 2014) and indirectly. Significant bioaccumulation steps occur between water and plankton (Manolopoulos et al. 2003) and between water and aquatic plants (Cosio et al. 2014). The direct relationships on bioavailability of $\mathrm{Hg}$ to plants are often plant-species-specific (Cosio et al. 2014). Relationships between sediment and plant Hg concentrations are also confounded by sediment characteristics and "biological dilution" effects (Lafabrie et al. 2011). MeHg has been found to move to, or form in, younger metabolically active plant tissues (Czuba and Mortimer 1980; Göthberg and Greger 2006). Herbivory can also be a direct link for $\mathrm{Hg}$ to fish and mammals, as younger plant tissues may be preferentially consumed. The indirect effects of aquatic plants on $\mathrm{Hg}$ fate and transport can be captured better by the models presented here, compared to the direct effects described by Cosio et al. (2014). These indirect effects include reduction of sediment resuspension and hydraulic mixing, increased retention of fine (high organic carbon) sediment, and alteration of the redox transition zone (where the sediment bed changes from aerobic to anaerobic) in the sediments; all caused by aquatic plant growth. These indirect effects, in turn, have a feedback influence on the growth of aquatic plants.

Environmental factors primarily affecting the growth of $V$. americana are TSS, wind fetch (Best et al. 2008), and water depth (Angradi et al. 2013). Sediment deposits over $10 \mathrm{~cm}$ will adversely affect $V$. americana beds, and sandy sediment deposited on vegetated beds is more damaging to plants than finer-grained material (Rybicke and Carter 1986). Others have found

2 Joel Hoffman, USEPA, email communication, March 2015 
that deposits of just 4-5 cm can limit propagule formation (Lacoul and Freedman 2006). It is likely that the placement of dredged material (average depth 1.7 meters in the construction zone) at $21^{\text {st }}$ Ave. will adversely affect preexisting stands of $V$. americana.

Water flow also affects the growth of aquatic plants. RTI International and URS (2013) found velocities in the estuary to be generally less than 0.1 $\mathrm{m} / \mathrm{s}$. Flow rates will exceed this at times and locations, especially in the main channel. In the cove, flow rates were measured to be less than 0.1 $\mathrm{m} / \mathrm{s}$ (Kreitinger 2015). Lacoul and Freedman (2006) report that water velocities of 0.3 to $0.4 \mathrm{~m} / \mathrm{s}$ are associated with the largest macrophyte biomass and species richness, while Madsen et al. (2001) report that flow rates of just $0.02-0.06 \mathrm{~m} / \mathrm{s}$ are ideal for photosynthesis. Madsen et al. (2001) further report that flow rates higher than $1 \mathrm{~m} / \mathrm{s}$ begin to limit plant growth. Therefore, flow rates in the St. Louis River estuary are suitable for the growth of aquatic plants. Once grown, macrophyte beds generally retard the flow of water, contribute to the accumulation of organic carbon in sediments, and provide a sink for particulates (Carpenter and Lodge 1986). Particulate settling highly influences aquatic plant growth in a positive way, by providing a supply of nutrients, but also negatively if the accumulation of organic matter leads to excessively anoxic conditions (Madsen et al. 2001). Sediment erosion can therefore be helpful to aquatic plants if it alleviates the build-up of anoxic organic matter. Plant surface area of $V$. americana was found to account for a $70 \%$ reduction in water flow when water depth effects were removed (Petticrew and Kalff 1992). Plant surface area was also related to clay content in lake sediments (Petticrew and Kalff 1992). Studies of hydraulic retention times in constructed wetlands increased by a factor of two compared to nonvegetated areas, partly because plants transfer large volumes of water to the atmosphere by evapotranspiration (Holcová et al. 2009). Flume studies have shown up to an $80 \%$ reduction in bed shear stress due to the presence of significant vegetation densities (Baptist et al. 2003). Plantassociated changes to the hydrodynamics of a site will have indirect effects on $\mathrm{Hg}$ fate and transport.

Bed shear stress, erosion, and SAV growth are coupled processes in aquatic systems (Teeter et al. 2001). In the models presented here, the hypothesized growth of aquatic plants is assumed to have long-term effects on sediment resuspension. $V$. americana led to the accumulation of fine sediments in studies by Petticrew and Kalff (1992), but $V$. americana 
can grow in substrates ranging from hard clay to gravel (Angradi et al. 2013). As submerged macrophyte beds age, the accumulation of organic matter increases in the sediments. This eventually leads to the growth of emergent plants (Carpenter and Lodge 1986). Large fluctuations in plant biomass can occur in aquatic systems (Carpenter and Lodge 1986). Therefore, the life-cycle of aquatic plants, both seasonally and over longer periods of time, will greatly contribute to the sediment dynamics at the site. It is likely that substrate conditions at the sediment surface will not limit the growth of aquatic plants; however, changes to the sediment will occur due to aquatic plants, both seasonally and long-term. In addition, Kingsbury Bay "biomedium" was used as a surficial material at $21^{\text {st }}$ Ave. cove to promote the growth of aquatic vegetation. Kingsbury Bay is located approximately 4.5 miles upriver on the Minnesota shore and contains a variety of native submerged and emergent aquatic plants. The sediment there contains plant propagules. This is thought to promote the initial growth of aquatic plants, but will not determine the final sediment characteristics of the area after the establishment of aquatic plants.

The growth of $V$. americana will likely increase the redox potential (Eh) of the sediments in the root zone. Submersed vascular plants generally oxidize their rhizospheres (Carpenter and Lodge 1986). The Eh is significantly higher at vascular plant sites relative to non-vegetated areas (Jaynes and Carpenter 1986). Generally aquatic plants increase the oxygen in aquatic environments (Nishihara and Ackerman 2007; Caraco et al. 2006), though floating-leaf vegetation can vent oxygen to the atmosphere, resulting in large reductions of oxygen in aquatic systems (Caraco et al. 2006). Higher dissolved oxygen is also conducive to further $V$. americana seed germination (Jarvis and Moore 2008). The redox transition zone is thought to be where most MeHg is formed.

Aquatic plants are a source of DOC to surface waters, and during plant decay, $30 \%$ of the plant biomass can be converted to DOC (Carpenter and Lodge 1986). Mercury binds to DOC, thus influencing $\mathrm{Hg}$ fate and transport. Aquatic plants are also a source of dissolved phosphorous during senescence (Carpenter and Lodge 1986), which influences algae formation and thus DOC. 


\section{HERMES Model}

Changing parameter inputs to the HERMES model (Ethier et al. 2010) as a result of the creation of shallow-water vegetated habitat was explored. HERMES is a mass balance model intended for lakes (Ethier 2009). Input parameters were estimated, and some input parameters were modified to simulate changes that were expected to occur during restoration. The modified input parameters included water depth, suspended particulate matter, sediment resuspension, hydraulic retention time, sediment total organic carbon (TOC), and redox in sediment. HERMES is contained in Microsoft Excel spreadsheets, determines steady-state conditions, and requires fixed ratios between the different forms of $\mathrm{Hg}\left(\mathrm{Hg}^{\circ}, \mathrm{MeHg}\right.$, and inorganic $\mathrm{Hg}^{2+}$ (hereafter referred to simply as $\mathrm{Hg}^{2+}$ )). HERMES cannot incorporate temporal changes, such as seasonal and long-term growth variations in aquatic plants, or Lake Superior seiching variations. "Running" HERMES is nearly instantaneous. Table 1 provides inputs that were held constant in the HERMES model for both the "no-action" and "restoration" scenarios.

Table 1. Constant input parameters for the HERMES model.

\begin{tabular}{|l|l|l|l|}
\hline Input & Value & Units & Reference \\
\hline Concentration of Hg in Air & 1.52 & $\mathrm{ng} / \mathrm{m}^{3}$ & Ethier et al. 2010 \\
\hline $\begin{array}{l}\text { Precipitation Rate (Rain and } \\
\text { Snowfall) }\end{array}$ & 0.91 & $\mathrm{~m} / \mathrm{year}$ & Ethier et al. 2010 \\
\hline Water Temperature & 10.5 & ${ }^{\circ} \mathrm{C}$ & Babiarz et al. 2012 \\
\hline Surface Area of Model Domain & 426,000 & $\mathrm{~m}^{2}$ & $\begin{array}{l}\text { Site Maps, Detroit District, } \\
2013\end{array}$ \\
\hline $\begin{array}{l}\text { Concentration of Total Hg in Inflow } \\
\text { Water }\end{array}$ & 2 & $\mathrm{ng} / \mathrm{L}$ & Dove et al. 2012; Beck 2013 \\
\hline Dissolved Organic Carbon & 20 & $\mathrm{mg} / \mathrm{L}$ & Berndt and Bavin 2012 \\
\hline $\begin{array}{l}\text { Suspended Particulate Matter in } \\
\text { Inflow }\end{array}$ & 20 & $\mathrm{mg} / \mathrm{L}$ & Babiarz et al. 2012 \\
\hline Settling Rate of Solids & 1 & $\mathrm{~g} / \mathrm{m}^{2} /$ day & Ethier et al. 2010 \\
\hline
\end{tabular}

The concentration of $\mathrm{Hg}$ in the air and the precipitation rate were set as default values designed for Ontario, Canada, lakes (Ethier et al. 2010). Water temperature for the St. Louis River estuary was obtained from Angradi et al. (2013). Depth (in meters) and areas (in square meters) were converted from USACE Detroit District site maps and project fact sheets. 
The model domain (Figure 1 ) is about $1 / 5^{\text {th }}\left(426,000 \mathrm{~m}^{2}\right)$ of the entire project area. Studies by Dove et al. (2012) and Beck (2013) indicate that surface water $\mathrm{Hg}$ concentrations in the estuary average about $2 \mathrm{ng} / \mathrm{L}$. Estuary DOC was measured by Berndt and Bavin (2012) to be $20 \mathrm{mg} / \mathrm{L}$. Beck and Johnson (2014) reported that DOC in the estuary could reach levels up to $40 \mathrm{mg} / \mathrm{L}$. Data suggest that suspended particulate matter should be in the range of $20 \mathrm{mg} / \mathrm{L}$ from earlier studies by Erdmann et al. (1994), Bahnick and Markee (1985), and recently by Babiarz et al. (2012). Settling rates for specific particle sizes and particle density will likely change; however, the presence of aquatic vegetation will also change the types of suspended particles. Therefore, the rate of settling may be similar before and after restoration. A value of $1 \mathrm{~g} / \mathrm{m} 2 /$ day was obtained using a method by Ethier et al. (2010) and an average water depth of 1.2 meters. Table 2 provides varied inputs to predict changes in $\mathrm{Hg}$ in the cove as a result of restoration.

Table 2. Varied HERMES input parameters for no-action scenario vs. restoration scenario.

\begin{tabular}{|l|c|c|c|l|}
\hline Input & $\begin{array}{c}\text { Value } \\
\text { (No Action) }\end{array}$ & $\begin{array}{c}\text { Value } \\
\text { (Restoration) }\end{array}$ & Units & Reference \\
\hline Mean Water Depth & 2 & 0.3 & $\mathrm{~m}$ & $\begin{array}{l}\text { Site Designs, Detroit District, } \\
2013\end{array}$ \\
\hline Volume & $8.52 \mathrm{E}+5$ & $1.28 \mathrm{E}+5$ & $\mathrm{~m}^{3}$ & Area X Depth \\
\hline $\begin{array}{l}\text { Suspended Particulate } \\
\text { Matter }\end{array}$ & 20 & 15 & $\mathrm{mg} / \mathrm{L}$ & Horppila and Nurminen 2003 \\
\hline $\begin{array}{l}\text { Resuspension Rate } \% \\
\text { of Settling Rate) }\end{array}$ & 50 & 25 & $\%$ & Schulz and Gücker 2005 \\
\hline $\begin{array}{l}\text { Hydraulic Residence } \\
\text { Time }\end{array}$ & $9 \mathrm{E}-4$ & $1 \mathrm{E}-4$ & years & $\begin{array}{l}\text { Petticrew and Kalff 1992; Shi et } \\
\text { al. 2013; Kleeberg et al. 2010 }\end{array}$ \\
\hline Water Inflow Rate & $1.08 \mathrm{E}+5$ & $1.46 \mathrm{E}+5$ & $\mathrm{~m}^{3} / \mathrm{hr}$ & Volume / Residence Time \\
\hline TOC in Sediment & 4.7 & 11.4 & $\%$ & $\begin{array}{l}\text { Kleeberg 2010; Shulz and } \\
\text { Gücker 2005 }\end{array}$ \\
\hline Redox in Sediment & -100 & 125 & $\mathrm{mV}$ & $\begin{array}{l}\text { Jaynes and Carpenter 1986; } \\
\text { Wigand et al. 1997 }\end{array}$ \\
\hline
\end{tabular}

HERMES input values were selected based on site-specific studies when possible. However, changes to the input values as a result of the growth of aquatic plants were often estimated from studies that were not site specific. The reduction in depth was determined from design plans provided by the Detroit District. Researchers have found a general reduction of suspended particulate matter inside an SAV patch, relative to the outside, during the growing season (Horppila and Nurminen 2003). In 
general, a reduction in sediment resuspension is expected inside a patch of aquatic vegetation (see Figure 7 in Schulz and Gücker 2005). Residence times were calculated from the total volume and flow rates. The residence time for the no-action scenario was based on measured flow velocities for the cove $(0.04 \mathrm{~m} / \mathrm{s}$, as described by Kreitinger 2015) horizontally across a 2-meter-deep square area $\left(426,000 \mathrm{~m}^{2}\right)$. For the residence time of the restoration scenario, the same flow velocity across a 0.3 -meter-deep square area $\left(426,000 \mathrm{~m}^{2}\right)$ was used. A 100\% increased residence time was then an added assumption for the restoration scenario, based on changes in flow velocity caused by aquatic plants in laboratory flumes studies (Shi et al. 2013), changes in flow velocity in lowland rivers inside vs. outside of aquatic plant patches (Kleeberg et al. 2010), and changes in flow velocity around $V$. americana patches in lakes as a function of leaf area index (Petticrew and Kalff 1992). Despite this added increase, the retention time of the restored scenario was still nine times less than the no-action scenario. Sediment TOC is expected to increase inside beds of aquatic vegetation (see Figure 1 in Kleeberg et al. 2010; see Figure 7 in Schulz and Gücker 2005). This simulation tested a two-fold increase in TOC due to aquatic plants. Prior to restoration, the average TOC in the sediments at $21^{\text {st }}$ Ave. was $4.7 \%$. After placement of surficial "biomedium" from Kingsbury Bay, the surficial sediments will have an average TOC closer to $5.7 \%$. The increase due to aquatic plant growth provided a sediment TOC after restoration of $11.4 \%(5.7 \times 2)$. The root structures of vascular plants increases the oxygen in the sediments and thus the redox (Eh) also increases (Jaynes and Carpenter 1986). Wigand et al. (1997) found the redox potential for sediment root zones of $V$. americana to be $+125 \mathrm{mV}$. The HERMES model calculates the MeHg to total $\mathrm{Hg}$ ratio in the sediments based on the sediment TOC and Eh (different for the two model run scenarios). The true initial ratio in the placed surficial sediment "biomedium" (see later in the WASP model description) is unknown. The $\mathrm{MeHg}$ to total $\mathrm{Hg}$ ratio in the surface water was set to a measured value for the estuary of about $0.03^{3}$. The ratio in the air was left at the default value of 0.005 (Ethier et al. 2010).

\section{HERMES Results and Discussion}

The HERMES model "built in" pre-calculation method (based on TOC and redox) for estimating $\mathrm{MeHg}$ to total $\mathrm{Hg}$ ratio in the sediments for the noaction scenario provided a value of 0.009 . This is very close to the average

\footnotetext{
3 Nathan Johnson, email communication, June 2015
} 
measured value for similar areas in the estuary of $0.0075^{4}$. The calculated ratio in the sediments for the restoration scenario was 0.015, which was less than the average measured value of 0.05 for vegetated sites in the estuary5. In this way, the model was run with a ratio of $\mathrm{MeHg}$ to total $\mathrm{Hg}$ in the sediments for the restoration scenario greater than the no-action scenario. Steady-state concentrations of $\mathrm{MeHg}$ and total $\mathrm{Hg}$ provided by HERMES output are provided in Table 3 .

Table 3. HERMES steady-state results: Mercury concentrations in surface water and sediment.

\begin{tabular}{|c|c|c|c|c|c|c|}
\hline \multirow[b]{2}{*}{ Matrix or Media (units) } & \multicolumn{2}{|c|}{ Methylmercury } & \multirow[b]{2}{*}{$\begin{array}{l}\text { Percent } \\
\text { Increase }\end{array}$} & \multicolumn{2}{|c|}{ Total Mercury } & \multirow[b]{2}{*}{$\begin{array}{l}\text { Percent } \\
\text { Increase }\end{array}$} \\
\hline & $\begin{array}{l}\text { No } \\
\text { Action }\end{array}$ & Restoration & & $\begin{array}{l}\text { No } \\
\text { Action }\end{array}$ & Restoration & \\
\hline Total Surface Water (ng/L) & 0.060 & 0.060 & $0 \%$ & 1.99 & 1.95 & $-4 \%$ \\
\hline $\begin{array}{l}\text { Dissolved Surface Water } \\
(\mathrm{ng} / \mathrm{L})\end{array}$ & 0.0083 & 0.01 & $20 \%$ & 0.28 & 0.33 & $18 \%$ \\
\hline Bulk Sediment (ng/g) & 0.015 & 0.046 & $206 \%$ & 1.66 & 2.57 & $55 \%$ \\
\hline Sediment Porewater (ng/L) & 0.0083 & 0.027 & $225 \%$ & 0.94 & 1.51 & $61 \%$ \\
\hline
\end{tabular}

The MeHg concentrations increased in the sediment due to the combined effect of input changes to simulate restoration. This includes the hydraulic residence time, which was calculated to decrease overall as a result of the restoration (Table 2). There may be less flushing (increased residence time) in the cove as a result of plant growth, and further modeling could explore this input parameter. The final steady-state ratios of $\mathrm{MeHg}$ to total $\mathrm{Hg}$ were well maintained as the model fixes these ratios (the slight increase in the ratio of $\mathrm{MeHg}$ to total $\mathrm{Hg}$ in the sediments for the restoration scenario (to 0.018 ) was probably due to rounding errors). The model shows that $\mathrm{Hg}$ concentrations in the surface water change less than in the sediments. This is to be expected, since the model has the cove hydraulically connected to the estuary for both scenarios (by the model design). However, the $\mathrm{Hg}$ in the dissolved surface water had a general increase (18-20\%), even though the DOC was unchanged between the noaction and restoration scenarios. The greater increases of $\mathrm{Hg}$ in the sediment porewater relative to the bulk sediments are also consistent with this trend. This HERMES model run fails to incorporate the reduction in bulk phase sediment concentrations between the no-action and restoration

4 Nathan Johnson, email communication, June 2015

5 Nathan Johnson, email communication, June 2015 
scenario. The placed sediment has, in fact, lower total Hg concentrations than the initial native sediment at the site. The only $\mathrm{Hg}$ concentrations entered into the HERMES model were the total inflow water (at $2 \mathrm{ng} / \mathrm{L}$ ). Bulk phase $\mathrm{Hg}$ concentrations in the sediment are probably highly influenced by the changes to the input sediment TOC content. Incorporating the true reductions in placed surficial sediment $\mathrm{Hg}$ concentrations relative to the existing sediments might be accomplished by using the "emission from underlying sediment $(\mathrm{kg} / \mathrm{yr})$ " input in the HERMES model. This value may then be altered for the restoration scenario to account for reductions in the bulk phase total $\mathrm{Hg}$ concentrations. However, if this emission were known, it would in some ways defeat the purpose of running a model. Furthermore, the long-term restoration itself (including plant growth) will further change bulk phase $\mathrm{Hg}$ concentrations from the placed surficial sediment at the site. Too many assumptions were required to utilize the emission input in the HERMES model. By not directly inputting the bulk phase concentrations, HERMES has an inherent safety factor (i.e., the model is conservative). Other areas in the estuary that are vegetated generally have a higher $\mathrm{MeHg}$ to total $\mathrm{Hg}$ ratio in the sediments relative to the restored scenario output in HERMES. This indicates that the HERMES model might be less conservative. The basis for the constant ratios, used in HERMES, is that many lakes have consistent ratios. However, this assumption may not hold for a system that is being transformed from an estuary cove with a hardened shoreline, to a shallow vegetated environment. Such a transitional system may never reach a steady-state ratio between $\mathrm{MeHg}$ and total $\mathrm{Hg}$ in the sediment or surface water. Since sediment concentrations at time zero can be known, a model that incorporates all of this information may be more realistic. A sensitivity analysis on the surface water $\mathrm{Hg}$ concentrations may translate into the variability observed in the sediment concentrations. This may be explored in future efforts using HERMES. 


\section{WASP Model}

The WASP is a mechanistic compartment model that is designed for rivers and estuaries (Wool et al. 2001). The equations solved by WASP are based on the conservation of mass. WASP traces each water quality constituent from the point of spatial and temporal input to its final model output. To perform these mass balance computations, input parameters were needed for initial $\mathrm{Hg}$ concentrations, physical site characteristics, rates of reactions, dispersive mixing, liquid and solid flows, and atmospheric exchange. These inputs, together with the general WASP mass balance equations and specific chemical kinetic equations, define a set of water quality equations. These are numerically integrated by WASP as the simulation proceeds in time. "Running" the WASP model generally takes several minutes or longer, depending on the complexity (the WASP model presented here took approximately 40 minutes to run). WASP output provides $\mathrm{Hg}$ concentrations in surface water and sediment over time. Therefore, it is possible to include some empirical temporal variations in WASP.

This WASP simulation is a one-box model with four vertical layers (called segments): surface water, mixed sediment layer, sediment methylation layer, and a deep sediment layer. The duration of this WASP simulation was 10 years, but ignores seasonal variations and shorter lake seiching oscillations. The spatial boundary of this model (model domain) is defined by the area enclosed by the yellow line drawn in the Figure 1 .

Previous WASP modeling has been conducted for the entire St. Louis River Estuary (RTI and URS 2013). The results of the effort showed that, between December 2004 and December 2011, total Hg concentrations in bulk sediment slowly decreased from 190 to $185 \mathrm{ng} / \mathrm{g}$ (a change that may not be significant). This previous WASP estuary model (hereafter referred to as the "RTI model") contains $21^{\text {st }}$ Ave. in a $1 \times 10^{6} \mathrm{~m}^{3}$ box on the bank of "segment 13." The WASP model presented here focuses on a volume (1X105 to $9 \times 10^{5} \mathrm{~m}^{3}$ ) that is inside the $1 \times 10^{6} \mathrm{~m}^{3}$ box of the RTI model.

\section{Mercury Concentrations}

The total Hg concentrations in WASP were set according to the measurements by Dr. Nathan Johnson ${ }^{6}$, which were in the range of values

6 email communication, June 2015 
reported earlier by Beck (2013) and Dove et al. (2012) for water concentrations; and the USACE Detroit District (2008), and LimnoTech (2013) for sediment concentrations. However, in these other studies, $\mathrm{MeHg}$ was not directly measured. Furthermore, filtered and unfiltered surface water $\mathrm{MeHg}$ were not measured in these other studies. Therefore, the $\mathrm{MeHg}$ and total $\mathrm{Hg}$ analysis provided by Dr. Nathan Johnson was more informative and was chosen to establish initial conditions in WASP.

In the St. Louis River Estuary, 20-50\% of the baseline suspended Hg has been reported to be dissolved (Glass et al. 1990). Recently, average total $\mathrm{Hg}$ concentrations were measured to be $2.1 \mathrm{ng} / \mathrm{L}^{7}$. The average filtered total $\mathrm{Hg}$ in the surface water was measured to be $1.6 \mathrm{ng} / \mathrm{L}^{8}$, which is $76 \%$ dissolved (higher than that reported earlier by Glass et al. 1990). Approximately $10-30 \%$ of most dissolved surface water $\mathrm{Hg}$ is in the $\mathrm{Hgo}$ elemental state (Ullrich et al. 2001). The filtered $\mathrm{MeHg}$ to total $\mathrm{Hg}$ ratio in dissolved surface water of the estuary can range from about 0.02 to $0.07^{9}$. The total $\mathrm{Hg}$ in the dissolved surface water was assumed to be in the following forms: $20 \%$ was $\mathrm{Hg}^{\circ}, 2 \%$ was $\mathrm{MeHg}$, and the remaining $78 \%$ was $\mathrm{Hg}^{2+}$. This was utilized for setting up initial dissolved surface water conditions in WASP.

Baseline TSS was assumed to be $20 \mathrm{mg} / \mathrm{L}$ in the surface water (as previously described), with about $3 \%$ organic carbon associated with that suspended material (data for "Lower Estuary Flats," Beck 2013). It was assumed that there was no suspended sand, and that all the suspended material was fines and organic matter; thus 19.4 and $0.6 \mathrm{mg} / \mathrm{L}$ were assumed as initial conditions for suspended fines, and organic matter associated with those fines, respectively (totaling $20 \mathrm{mg} / \mathrm{L}$ ). It was assumed that $50 \%$ of the fines were colloidal and remained in suspension for long periods of time, and that 50\% of the organic matter associated with those fines remained in suspension as well. This assumption is based on the fact that TSS in the estuary is maintained at about $10 \mathrm{mg} / \mathrm{L}$ (Bahnick and Markee 1985; Kreitinger 2015). Dissolved organic carbon was set at $20 \mathrm{mg} / \mathrm{L}$, which is a reasonable estimate from Berndt and Bavin (2012) and Beck and Johnson (2014). DOC is entered independently from suspended particulate matter in WASP. The DOC was assumed to not

\footnotetext{
7 Nathan Johnson, email communication, June 2015

8 Nathan Johnson, email communication, June 2015

${ }^{9}$ calculations based on measurements provided by Nathan Johnson, email communication, June 2015
} 
include organic matter associated with suspended colloids (silt and fines). Silts and fines are not distinguishable in the WASP model.

Site-specific partitioning for $\mathrm{MeHg}$ and $\mathrm{Hg}^{2+}$ between sediment solids and sediment porewater are similar, about 103 and $105 \mathrm{~L} / \mathrm{kg}$, respectively ${ }^{10}$. These values were similar to values in online WASP user's guidance (USEPA 2015), and used for calculation of initial conditions in WASP. $\mathrm{Hg}^{\circ}$ partitioning was assumed to be $\mathrm{o} / \mathrm{kg}$ based on WASP user's guidance (USEPA 2015). Other studies confirmed that $\mathrm{Hg}^{\circ}$ does not bind to solids (Hsu-Kim et al. 2013). Bulk-phase concentrations of total Hg (assumed to be primarily $\mathrm{Hg}^{2+}$ ) before and after placement at $21^{\text {st }}$ Ave. were measured to be 226 and $118 \mathrm{ng} / \mathrm{g}$, respectively ${ }^{11}$. Similarly, LimnoTech (2013) found total $\mathrm{Hg}$ concentrations to range from 50 to $500 \mathrm{ng} / \mathrm{g}$ in the sediment at $21^{\text {st }}$ Ave. For MeHg, bulk phase sediment concentrations before and after placement were 0.91 and $0.89 \mathrm{ng} / \mathrm{g}$, respectively ${ }^{12}$. Kingsbury Bay sediment, with a mean bulk sediment $\mathrm{Hg}$ concentration of $8 \mathrm{o} \mathrm{ng} / \mathrm{g}$ total $\mathrm{Hg}$ (range 20 to $240 \mathrm{ng} / \mathrm{g}$ ), will be placed as a surficial layer of $1.0 \pm 0.5 \mathrm{ft}$ (about $30.5 \mathrm{~cm}$ ) thickness at $21^{\text {st }}$ Ave. This is similar to the range in concentrations of the previously placed dredged material; however, it is possible that the ratio of $\mathrm{MeHg}$ to total $\mathrm{Hg}$ in the Kingsbury Bay sediment is quite different from the previously placed dredged material. Without direct $\mathrm{MeHg}$ measurements of Kingsbury Bay sediment, $\mathrm{MeHg}$ concentrations and total $\mathrm{Hg}$ concentrations of the placed surficial sediment at $21^{\text {st }}$ Ave. were assumed to be $118 \mathrm{ng} / \mathrm{g}$ and $0.89 \mathrm{ng} / \mathrm{g}$, respectively, for the WASP model initial conditions. Initial bulk phase concentrations of $\mathrm{Hg}^{\circ}$ were assumed to be $\mathrm{o} \mathrm{ng} / \mathrm{g}$.

Using previously mentioned partitioning and bulk-phase sediment concentrations of total $\mathrm{Hg}$ (assumed to be $\mathrm{Hg}^{2+}$ ) and $\mathrm{MeHg}$, porewater concentrations were calculated. The units of ng/L porewater were converted to ng in porewater per gram solids in that layer by using typical porosity values for placed fine sediments ( 0.85 for the mixed layer and 0.75 for the deep sediments ${ }^{13}$ ) and a solids specific gravity of 2.65. WASP input requires partitioning between components of sediment: silts and fines, sand, and organic matter. Therefore, WASP user's guidance (USEPA 2015) and suggestions from Dr. Nathan Johnson were used to set

\footnotetext{
10 Nathan Johnson, email communication, June 2015

11 Nathan Johnson, email communication, June 2015

12 Nathan Johnson, email communication, June 2015

13 Paul Schroeder, personal communication, September 2014
} 
partitioning to these specific particle types in the sediments. For inorganic $\mathrm{Hg}^{2+}$, the partitioning to silts/fines, sand, and organics were set at 105, 104, and $106 \mathrm{~L} / \mathrm{kg}$, respectively. For MeHg, the partitioning to silts/fines, sand, and organics were set to 103, 102, and $104 \mathrm{~L} / \mathrm{kg}$, respectively. None of the silt/fines, sand, or organic matter associated with those fines were assigned as dissolved-in-the-sediment porewater (in WASP).

\section{Physical Site Characteristics}

The organic matter in the sediments was set to be $4.7 \%$ as previously described for the HERMES model. An increased TOC due to aquatic plant growth was not set as an initial condition in the WASP simulation of the restoration scenario. Most of the placed sediment was finer than sand. Sieving of the sediment showed that 3.4\% (a median value) was course material. Subtracting the percent coarse particles and organic matter yields 91.9\% mineral (non-organic) silt and fines. As described earlier, segment volume, depth, and areas were obtained from USACE Detroit District site maps and project fact sheets. The formation of MeHg occurs primarily in anaerobic sediments that are located centimeters below the sediment surface. Therefore, a sediment methylation layer $(2 \mathrm{~cm}$ thickness) was modeled beneath a mixed (aerobic) sediment layer $(5 \mathrm{~cm}$ thickness). Wind speed $(5 \mathrm{~m} / \mathrm{s})$ and air temperature $\left(15^{\circ} \mathrm{C}\right)$ was set according to the National Oceanic and Atmospheric Administration (NOAA 1998). Babiarz et al. (2012) reported water temperatures in the St. Louis River to be $10.5^{\circ} \mathrm{C}$ (as used in the HERMES model).

\section{Reaction Rates}

The overall WASP conceptual model is depicted in Figure 3, which also shows additional chemical kinetic transformations from oxidation, reduction, methylation, and demethylation of $\mathrm{Hg}$. These kinetic rates are largely unknown and are influenced by many factors, such as light, temperature, $\mathrm{DOC}, \mathrm{pH}$, redox conditions, and the form and concentration of organic carbon and sulfur in the sediments. There is limited information in the literature on how to calculate $\mathrm{Hg}$ transformation rates based on these factors. It is also difficult to measure all of these factors. Demethylation was set to be 0.0002 and 0.00002 day $^{-1}$ in the water and sediment, respectively, based on the RTI model. WASP user's guidance (USEPA 2015) suggests the range of possible oxidation rates to be from 0.001 to 0.1 day $^{-1}$. The lowest value in the range (0.001) was selected, based on the RTI model, for the surface water layer and mixed sediment 
layer (which are considered aerobic). Reduction of $\mathrm{Hg}^{2+}$ due to sunlight was set at the lowest recommended levels in WASP user's guidance (0.001 day $^{-1}$ ) for the surface water (USEPA 2015), because turbidity has been significant in the St. Louis River estuary following the 2012 flood. This value for reduction of $\mathrm{Hg}^{2+}$ was also used in the RTI model.

Figure 3. WASP conceptual model: A box model with four segments and surface water boundaries.

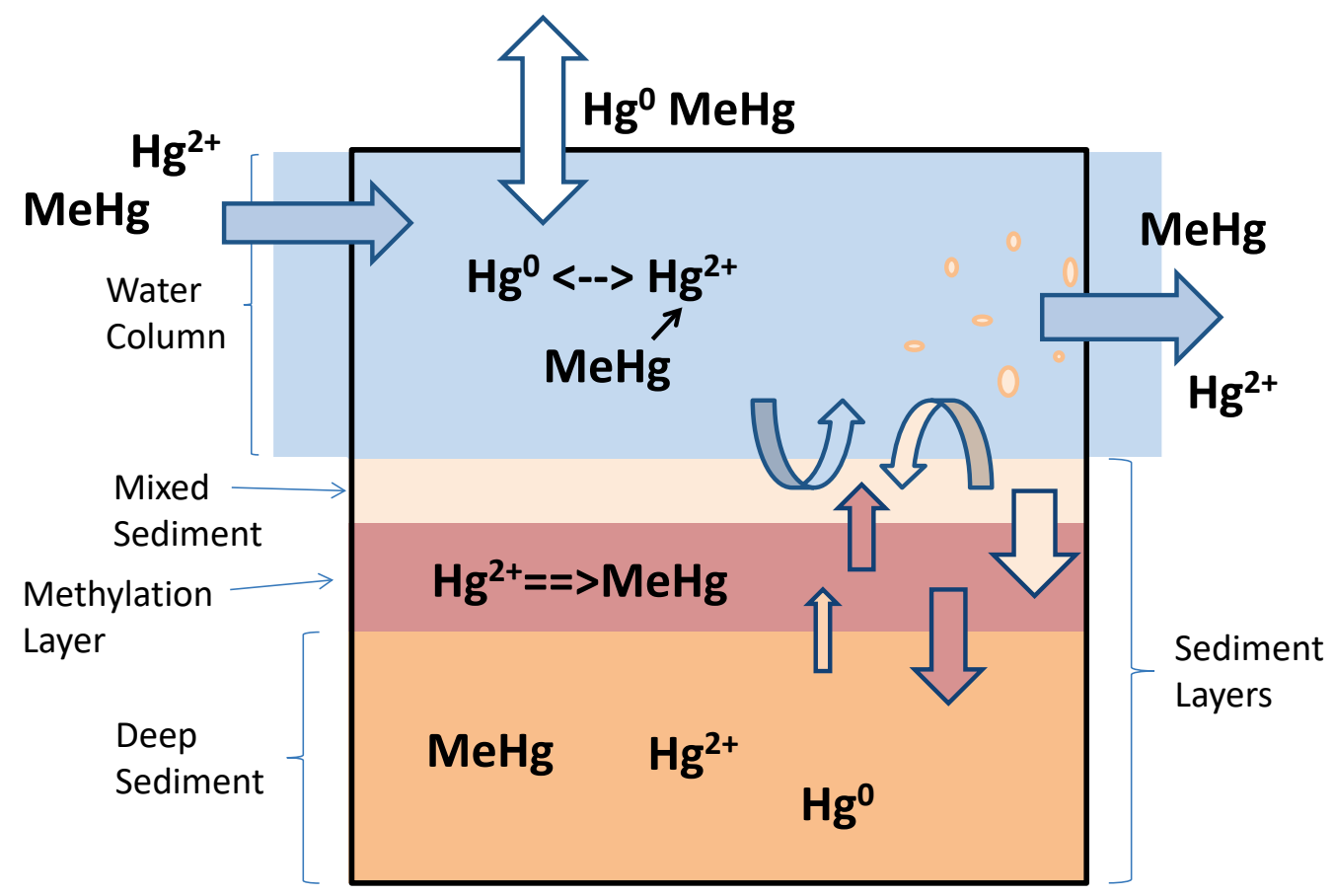

Methylation rates were estimated from Drott et al. (2007) based on a productive mineral-dominated freshwater sediment with carbon to nitrogen $(\mathrm{C} / \mathrm{N})$ ratios and total carbon $(\mathrm{C})$ content similar to the lower St. Louis River estuary. This value of 0.01 day $^{-1}$ was then decreased by an order-of-magnitude (to 0.001 day $^{-1}$ ) for the WASP model, to account for spiked $\mathrm{Hg}$ in a laboratory setting (in Drott et al. 2007). This was also in the range of methylation rates recommended by WASP user's guidance (0.00001-0.01 day-1) (USEPA 2015). The RTI model used methylation rates of 0.0001 and 0.00002 day $^{-1}$ for the water and sediment, respectively. However, this does not make sense, because methylation occurs primarily in the sediments at the redox transition zone. The peak sediment methylation rate should therefore be higher than the surface water methylation rate (Ullrich et al. 2001). Knightes (2008) used a midpoint value of 0.014 day $^{-1}$ (range 0.00014 to 0.028 ) for methylation rate in the SERAFM model (described in detail later). In this WASP simulation, a mid-range value for methylation was selected (0.001 day ${ }^{-1}$ in the sediment 
methylation layer). Methylation rates were not altered between WASP model scenarios (runs).

\section{Mixing}

There is dispersive exchange (mixing) of surface water and suspended solids between the model domain (the cove) and boundaries (the surrounding St. Louis River estuary). In the WASP simulation presented here, mixing across the yellow line, in Figure 1, is difficult to estimate. Depending on the flow direction in the river (which depends on 8-hour seiching periods from Lake Superior), the WLSSD effluent can shift direction, causing the effluent plume to flow more or less into the cove over time. WASP user's guidance (USEPA 2015) suggests $1 \mathrm{E}-5 \mathrm{~m}^{2} / \mathrm{s}$ as a typical dispersive exchange for estuaries. The RTI model used values in the range of 5 to $10 \mathrm{~m}^{2} / \mathrm{s}$ for dispersive longitudinal mixing. The mixing between this WASP model domain and the boundaries would be representative of lateral mixing in the estuary. WASP user's guidance (USEPA 2015) suggests lateral mixing should be an order-of-magnitude less than longitudinal mixing. Therefore, a value of $0.75 \mathrm{~m}^{2} / \mathrm{s}$ (an order of magnitude less than the mid-range longitudinal mixing) was selected for dispersive exchange (lateral mixing) between the cove and the estuary (i.e., model domain and boundary). This is much higher than suggested by WASP user's guidance (USEPA 2015) for typical dispersive exchange in estuaries. However, the St. Louis River estuary may not be a typical estuary in terms of dispersive exchange, and this high value may also account for the additional mixing due to the WLSSD effluent plume (which is adjacent to the cove).

The cross-sectional area (surface area dictating horizontal movement) between the water column and the boundary $\left(800 \mathrm{~m}^{2}\right.$ before placement, and $120 \mathrm{~m}^{2}$ after placement) was estimated as the product of the average water depth ( $2 \mathrm{~m}$ before placement, and $0.3 \mathrm{~m}$ after placement) and the distance of this interface (400m), as determined from Google Maps (Figure 1). The characteristic mixing length (200 $\mathrm{m}$ ) for this dispersive exchange was set to approximately the lateral distance from this interface, to the center of the model domain, when looking down from a "bird's-eye view."

Dispersive exchange $\left(5 \mathrm{E}-8 \mathrm{~m}^{2} / \mathrm{s}\right)$ was set between all sediment segment layers according to the RTI model. The areas dictating vertical movements were set equal to horizontal areas of those sediment layers, again looking 
down from a "bird's-eye view." The characteristic mixing length (for vertical movement) was set equal to the depth of the mixed layer (0.05 $\mathrm{m}$ ). The RTI model used a mixing length of $0.05 \mathrm{~m}$ for a mixed sediment layer (a common bioturbation depth).

\section{Flows}

As previously mentioned, RTI International and URS (2013) estimated velocities in the estuary to be generally less than $10 \mathrm{~cm} / \mathrm{s}$. However, the cove has measured velocities of approximately $4 \mathrm{~cm} / \mathrm{s}$ (Kreitinger 2015). The flow rate calculated through the horizontal cross section (range 120 to $800 \mathrm{~m}^{2}$ ) using this velocity was 4 and $30 \mathrm{~m}^{3} / \mathrm{s}$ for the restored and noaction scenarios, respectively. Additional flow to the cove occurs from Miller and Coffee Creeks, but these flows are minimal (0.1 to $1.4 \mathrm{~m} 3 / \mathrm{s}$ ) (Anderson et al. 2000) and are not included in this WASP model simulation. After restoration, it is reasonable that the proportion of the flow from the creeks relative to the estuary boundary will increase, especially during snowmelt. This is due to shallower water depths after dredged material placement, and the effect that aquatic plants have on hydraulic retention time and hydraulic mixing from the estuary. This was explored more specifically through use of the SERAFM model (described later). The flow from the WLSSD effluent is generally $1.7 \mathrm{~m} 3 / \mathrm{s}$ (Host et al. 2013). However, the effluent does not discharge directly into the model domain. Instead, the effluent discharges into the boundary of the model domain (as previously described). The WLSSD flow to the model boundary was not included in this WASP simulation. The changes in surface water Hg concentrations caused by the WLSSD were not modeled in this WASP simulation.

Porewater flows were assumed to be zero, but can be changed to account for advective transport of dissolved $\mathrm{Hg}$ if more information about groundwater discharge at the site is obtained. Advective flows of solids are assigned independently. Organic solids are associated with $\mathrm{Hg}$, while mineral solids are separate from Hg. Only three solid types can be selected in the "particulate transport field" of the "system data" in WASP: Hgo was set as "solids 1"; $\mathrm{Hg}^{2+}, \mathrm{MeHg}$, and organic matter were set as "solids 2;" and sand/silts/fines were set as "solids 3." This influences how Hg moves from one segment to another by advective flows. The model was set to obtain a mass balance on MeHg alone (only one can be selected). 
Advective flows of solids were derived from resuspension, settling, and burial rates (in m/year). Settling was chosen to be typical of particulate organic carbon, clay, and silt in natural waters (from Chapra 1997), and burial was chosen as typical for estuary coves or backwater embayments ${ }^{14}$. Resuspension was determined as the difference required to balance settling and burial, as derived by the USACE RECOVERY model (Boyer et al. 1994). An estimate of the bulk density of the sediment (in the case of resuspension and burial) was used to derive advective flows of solids for these processes in units of $\mathrm{m}^{3} / \mathrm{s}$. In the case of settling velocity ( $\mathrm{m} /$ year), the additional knowledge of average settleable particulate concentration $(10 \mathrm{mg} / \mathrm{L})$ and estimated particle density was used to determine this advective solids flow in the units required for WASP. Because the units of WASP are not in the standard units that these sediment processes are typically described, advective flows of solids are some of the most difficult inputs to work with.

\section{Air-Water Exchange}

WASP calculates surface-water-atmosphere Hg exchange as a net volatilization rate. This requires a volatilization rate constant calculated internally from the wind speed, water velocity, water depth, and temperature. It also requires a Henry's Law constant, which was obtained from the literature (Jonsson et al. 2010). Henry's Law constants were similar for both $\mathrm{MeHg}$ and $\mathrm{Hg}^{\circ}$ (0.0072 and $0.00673 \mathrm{~atm} \mathrm{~m} 3 / \mathrm{mol}$ ), according to Jonsson et al. (2010), and converted to the desired units using the USEPA's online unit converter (USEPA 2015b). Typically only $\mathrm{Hg}^{\circ}$ has been considered volatile in previous WASP models. Precipitation and evaporation exchanges of water were also entered into WASP according to values obtained from the literature (Glass and Sorensen 1999; Hall et al. 2005). However, these exchanges did not include any $\mathrm{Hg}$ species. Instead, the surface area of the model domain was used to calculate a total load of $\mathrm{Hg}$ input by precipitation, which was negligible relative to $\mathrm{Hg}$ associated with flows coming in from the St. Louis River Estuary water column boundary. This is also where evapotranspiration could be incorporated into the WASP model though it was not done in this study. WASP inputs are provided in Table 4.

\footnotetext{
14 Paul Schroeder, personal communication, September 2014
} 
Table 4. Inputs/initial conditions for the WASP box (4 segment) model.

\begin{tabular}{|c|c|c|c|c|c|c|c|c|c|c|}
\hline & Atmosphere & units & Water Layer & units & Mixed Layer & units & Methylation Layer & units & Deep Sediments & units \\
\hline Water Volume & - & & 127,800 to 852,000 & $\mathrm{~m}^{3}$ & 21,300 & $\mathrm{~m}^{3}$ & 8,520 & $\mathrm{~m}^{3}$ & 630,480 & $\mathrm{~m}^{3}$ \\
\hline Water Depth & - & & 0.3 to 2 & $\mathrm{~m}$ & 0.05 & $\mathrm{~m}$ & 0.02 & $\mathrm{~m}$ & 1.48 & $\mathrm{~m}$ \\
\hline Surface Area Horizontal & - & & 120 to 800 & $m^{2}$ & - & & - & & - & \\
\hline Surface Area Vertical & - & & 426,000 & $m^{2}$ & 426,000 & $\mathrm{~m}^{2}$ & 426,000 & $m^{2}$ & 426,000 & $\mathrm{~m}^{2}$ \\
\hline Temperature & 15 & ${ }^{\circ} \mathrm{C}$ & 10.5 & ${ }^{\circ} \mathrm{C}$ & 10.5 & ${ }^{\circ} \mathrm{C}$ & 10.5 & ${ }^{\circ} \mathrm{C}$ & 10 & ${ }^{\circ} \mathrm{C}$ \\
\hline Horizontal Surface Dispersion & - & & 7.50E-01 & $\mathrm{m}^{2} / \mathrm{s}$ & 0 & $\mathrm{~m}^{2} / \mathrm{s}$ & 0 & $\mathrm{~m}^{2} / \mathrm{s}$ & 0 & $\mathrm{~m}^{2} / \mathrm{s}$ \\
\hline Vertical Porewater Diffusion & - & & 5.00E-08 & $\mathrm{m}^{2} / \mathrm{s}$ & 5.00E-08 & $\mathrm{m}^{2} / \mathrm{s}$ & 5.00E-08 & $\mathrm{m}^{2} / \mathrm{s}$ & 5.00E-08 & $\mathrm{m}^{2} / \mathrm{s}$ \\
\hline Organic Solids Resuspension & - & & 8.77E-07 & $\mathrm{m}^{3} / \mathrm{s}$ & 0 & $\mathrm{~m}^{3} / \mathrm{s}$ & 0 & $\mathrm{~m}^{3} / \mathrm{s}$ & 0 & $\mathrm{~m}^{3} / \mathrm{s}$ \\
\hline Mineral Solids Resuspension & - & & 3.00E-05 & $\mathrm{m}^{3} / \mathrm{s}$ & 0 & $\mathrm{~m}^{3} / \mathrm{s}$ & 0 & $\mathrm{~m}^{3} / \mathrm{s}$ & 0 & $\mathrm{~m}^{3} / \mathrm{s}$ \\
\hline Organic Solids Settling & - & & 0 & $\mathrm{~m}^{3} / \mathrm{s}$ & 1.00E-06 & $\mathrm{m}^{3} / \mathrm{s}$ & 0 & $\mathrm{~m}^{3} / \mathrm{s}$ & 0 & $\mathrm{~m}^{3} / \mathrm{s}$ \\
\hline Mineral Solids Settling & - & & 0 & $\mathrm{~m}^{3} / \mathrm{s}$ & 3.40E-05 & $\mathrm{m}^{3} / \mathrm{s}$ & 0 & $\mathrm{~m}^{3} / \mathrm{s}$ & 0 & $\mathrm{~m}^{3} / \mathrm{s}$ \\
\hline Organic Solids Burial & - & & 0 & $\mathrm{~m}^{3} / \mathrm{s}$ & 0 & $\mathrm{~m}^{3} / \mathrm{s}$ & $1.23 \mathrm{E}-07$ & $\mathrm{~m}^{3} / \mathrm{s}$ & $1.23 \mathrm{E}-07$ & $\mathrm{~m}^{3} / \mathrm{s}$ \\
\hline Mineral Solids Burial & - & & 0 & $\mathrm{~m}^{3} / \mathrm{s}$ & 0 & $\mathrm{~m}^{3} / \mathrm{s}$ & $4.00 \mathrm{E}-06$ & $\mathrm{~m}^{3} / \mathrm{s}$ & 4.00E-06 & $\mathrm{m}^{3} / \mathrm{s}$ \\
\hline Horizontal Water Flow Through & - & & 4 to 30 & $\mathrm{~m}^{3} / \mathrm{s}$ & 0 & $\mathrm{~m}^{3} / \mathrm{s}$ & 0 & $\mathrm{~m}^{3} / \mathrm{s}$ & 0 & $\mathrm{~m}^{3} / \mathrm{s}$ \\
\hline Precipitation & - & & 0.0054 & $\mathrm{~m}^{3} / \mathrm{s}$ & 0 & $\mathrm{~m}^{3} / \mathrm{s}$ & 0 & $\mathrm{~m}^{3} / \mathrm{s}$ & 0 & $\mathrm{~m}^{3} / \mathrm{s}$ \\
\hline Evaporation & 0.0054 & $\mathrm{~m}^{3} / \mathrm{s}$ & - & & - & & - & & - & \\
\hline Wind Speed & 5 & $\mathrm{~m} / \mathrm{s}$ & - & & - & & - & & - & \\
\hline DOC & - & & 20 & $\mathrm{mg} / \mathrm{L}$ & 20 & $\mathrm{mg} / \mathrm{L}$ & 20 & $\mathrm{mg} / \mathrm{L}$ & 20 & $\mathrm{mg} / \mathrm{L}$ \\
\hline \multicolumn{11}{|l|}{ Initial Concentration (Total) } \\
\hline $\mathrm{Hg}(0)$ & 3.00E-09 & $\mathrm{g} / \mathrm{m}^{3}$ & 0.31 & $\mathrm{ng} / \mathrm{L}$ & 0 & $\mathrm{ng} / \mathrm{g}$ & 0 & $\mathrm{ng} / \mathrm{g}$ & 0 & $\mathrm{ng} / \mathrm{g}$ \\
\hline $\mathrm{Hg}(2+)$ & 3.00E-10 & $\mathrm{g} / \mathrm{m}^{3}$ & 1.72 & $\mathrm{ng} / \mathrm{L}$ & $118-226$ & $\mathrm{ng} / \mathrm{g}$ & $118-226$ & $\mathrm{ng} / \mathrm{g}$ & 226 & $n g / g$ \\
\hline MeHg & 3.00E-11 & $\mathrm{g} / \mathrm{m}^{3}$ & 0.07 & $n g / L$ & $0.89-0.91$ & $n g / g$ & $0.89-0.91$ & $n g / g$ & 0.91 & $n g / g$ \\
\hline
\end{tabular}




\begin{tabular}{|c|c|c|c|c|c|c|c|c|c|c|}
\hline & Atmosphere & units & Water Layer & units & Mixed Layer & units & Methylation Layer & units & Deep Sediments & units \\
\hline Silts and Fines & - & & 19.4 & $\mathrm{mg} / \mathrm{L}$ & 294 & $\mathrm{mg} / \mathrm{g}$ & 294 & $\mathrm{mg} / \mathrm{g}$ & 432 & $\mathrm{mg} / \mathrm{g}$ \\
\hline Sand & - & & 0 & $\mathrm{mg} / \mathrm{L}$ & 12.8 & $\mathrm{mg} / \mathrm{g}$ & 12.8 & $\mathrm{mg} / \mathrm{g}$ & 16 & $\mathrm{mg} / \mathrm{g}$ \\
\hline Organic Matter & - & & 0.6 & $\mathrm{mg} / \mathrm{L}$ & 15 & $\mathrm{mg} / \mathrm{g}$ & 15 & $\mathrm{mg} / \mathrm{g}$ & 22 & $\mathrm{mg} / \mathrm{g}$ \\
\hline \multicolumn{11}{|c|}{ Initial Concentration (Fraction Dissolved) } \\
\hline $\mathrm{Hg}(0)$ & - & & 1 & & 1 & & 1 & & 1 & \\
\hline $\mathrm{Hg}(2+)$ & - & & 0.76 & & $6.8 \mathrm{E}-6$ & & $6.8 \mathrm{E}-6$ & & $5.3 \mathrm{E}-6$ & \\
\hline $\mathrm{MeHg}$ & - & & 1 & & $6.8 \mathrm{E}-4$ & & $6.8 \mathrm{E}-4$ & & $5.3 \mathrm{E}-4$ & \\
\hline Silts and Fines & - & & 0.5 & & 0 & & 0 & & 0 & \\
\hline Sand & - & & 0 & & 0 & & 0 & & 0 & \\
\hline Organic Matter & - & & 0.5 & & 0 & & 0 & & 0 & \\
\hline \multicolumn{11}{|l|}{ Rates of Reactions } \\
\hline methylation rate & - & & 0 & day $^{-1}$ & 0 & day $^{-1}$ & 1.00E-03 & day $^{-1}$ & 0 & day $^{-1}$ \\
\hline demethylation rate & - & & 2.00E-04 & day $^{-1}$ & 2.00E-05 & day $^{-1}$ & 2.00E-05 & day $^{-1}$ & 0 & day $^{-1}$ \\
\hline oxidation rate & - & & $1.00 \mathrm{E}-03$ & day-1 & 1.00E-03 & day $^{-1}$ & 0 & day $^{-1}$ & 0 & day $^{-1}$ \\
\hline reduction rate & - & & $1.00 \mathrm{E}-03$ & day-1 & 0 & day $^{-1}$ & 0 & day $^{-1}$ & 0 & day $^{-1}$ \\
\hline
\end{tabular}


Though the values are listed in Table 4 above, a separate Table has been provided to highlight the inputs to the WASP model that were altered between the "no-action" and "restoration" scenarios (Table 5).

Table 5. WASP input parameters that were altered between the "no-action" and "restoration" scenarios.

\begin{tabular}{|l|l|l|}
\hline WASP Input & No Action & Restoration \\
\hline Water Volume $\left(\mathrm{m}^{3}\right)$ & 852,000 & 127,800 \\
\hline Water Depth $(\mathrm{m})$ & 2 & 0.3 \\
\hline Surface Area, Horizontal $\left(\mathrm{m}^{2}\right)$ & 800 & 120 \\
\hline $\begin{array}{l}\text { Horizontal Flow Through } \\
\left(\mathrm{m}^{3} / \mathrm{s}\right)\end{array}$ & 30 & 4 \\
\hline $\begin{array}{l}\text { Initial } \mathrm{Hg}{ }^{2+} \text { concentration in } \\
\text { mixed sediment and } \\
\text { methylation layers }(\mathrm{ng} / \mathrm{g})\end{array}$ & 226 & 118 \\
\hline $\begin{array}{l}\text { Initial MeHg concentration in } \\
\text { mixed sediment and } \\
\text { methylation layers }(\mathrm{ng} / \mathrm{g})\end{array}$ & 0.91 & 0.89 \\
\hline
\end{tabular}

\section{WASP Results and Discussion}

The WASP model was run for 10-year simulations. In the first year (or less), some of the outputs changed drastically and then reached a more gradual change over the latter nine years. This gradual change is described in Table 6. Judging by the nature of the trends, concentrations appeared close to steady state (within a factor of 2) after 10 years, but were not fully stabilized. For both the "no-action" and "restoration" scenarios, the percent of organic matter in the mixed layer of the sediment decreased from $4.7 \%$ to $4.5 \%$ over the 10 -year simulation. Future work could test which input parameter caused the change in organic matter. The total $\mathrm{Hg}^{2+}$ concentrations were presented, instead of total $\mathrm{Hg}$, because WASP does not generate total $\mathrm{Hg}$ output in the dissolved phase. However, the total $\mathrm{Hg}$ trends were fairly similar to total $\mathrm{Hg}^{2+}$ trends, and most aquatic environmental $\mathrm{Hg}$ is in the inorganic divalent state $\left(\mathrm{Hg}^{2+}\right)$. 
Table 6. Ten-year WASP mercury model results with trend descriptions (over the later nine years).

\begin{tabular}{|c|c|c|c|c|c|c|c|c|}
\hline \multirow{3}{*}{$\begin{array}{l}\text { Matrix or Media } \\
\text { (units) }\end{array}$} & \multicolumn{4}{|l|}{$\mathrm{MeHg}$} & \multicolumn{4}{|c|}{ Total $\mathrm{Hg}^{2+}$} \\
\hline & \multicolumn{2}{|c|}{ No Action } & \multicolumn{2}{|c|}{ Restoration } & \multicolumn{2}{|c|}{ No Action } & \multicolumn{2}{|c|}{ Restoration } \\
\hline & $\begin{array}{l}2013- \\
2022\end{array}$ & trend & $\begin{array}{l}2013- \\
2022\end{array}$ & trend & $\begin{array}{l}2013- \\
2022\end{array}$ & trend & $\begin{array}{l}2013- \\
2022\end{array}$ & trend \\
\hline Total Water (ng/L) & 0.8 & level & 0.8 & level & 4.5 & level & $\begin{array}{l}4.9 \text { to } \\
4.8\end{array}$ & $\begin{array}{l}\text { convex } \\
\text { decrease }\end{array}$ \\
\hline $\begin{array}{l}\text { Dissolved Water } \\
(\mathrm{ng} / \mathrm{L})\end{array}$ & 0.04 & level & 0.04 & level & 1.0 & level & $\begin{array}{l}1.2 \text { to } \\
1.1\end{array}$ & $\begin{array}{l}\text { convex } \\
\text { decrease }\end{array}$ \\
\hline $\begin{array}{l}\text { Bulk Sediments } \\
\text { (mixed layer) (ng/g) }\end{array}$ & $\begin{array}{l}2.5 \text { to } \\
3.9\end{array}$ & $\begin{array}{l}\text { steady } \\
\text { increase }\end{array}$ & $\begin{array}{l}2.5 \text { to } \\
3.9\end{array}$ & \begin{tabular}{|l} 
steady \\
increase
\end{tabular} & $\begin{array}{l}200 \text { to } \\
160\end{array}$ & $\begin{array}{l}\text { convex } \\
\text { decrease }\end{array}$ & $\begin{array}{l}200 \text { to } \\
165\end{array}$ & $\begin{array}{l}\text { convex } \\
\text { decrease }\end{array}$ \\
\hline $\begin{array}{l}\text { Porewater (mixed } \\
\text { layer) (ng/L) }\end{array}$ & 0.04 & level & 0.04 & level & $\begin{array}{l}1.4 \text { to } \\
1.1\end{array}$ & \begin{tabular}{|l} 
convex \\
decrease
\end{tabular} & $\begin{array}{l}1.4 \text { to } \\
1.1\end{array}$ & \begin{tabular}{|l} 
convex \\
decrease
\end{tabular} \\
\hline
\end{tabular}

The results of the WASP model show that the restoration has generally little effect on $\mathrm{Hg}$ concentrations, especially MeHg. This is due to the way the WASP model was applied, when compared to the HERMES model. The changes caused by aquatic plant growth (i.e., suspended particulate matter, sediment resuspension, TOC and redox in sediment, inflow $\mathrm{Hg}$ concentrations, and watershed characteristics) were not explicitly changed for the WASP restoration scenario, as they were in the HERMES model. Rather than creating a restoration scenario using inputs, the WASP model was run to see whether the model would induce the changes expected during long-term restoration. This WASP model was perhaps simulating a third scenario: where dredged material is placed and aquatic plants do not grow (or before plants grow). The rates of reaction (methylation and demethylation) were not changed between WASP model scenarios, but this may not be realistic. The rates of reaction are a good input for future model calibration.

WASP relies heavily on the partitioning coefficients of the different forms of $\mathrm{Hg}$ to the different particle types (silt/fines, sand, and organic matter). In a study conducted in the spring and fall of both 2000 and 2001, Manolopoulos et al. (2003) found that the concentrations of $\mathrm{MeHg}$ on particles in the St. Louis River increased (from about $2.5 \mathrm{ng} / \mathrm{g}$ to $7 \mathrm{ng} / \mathrm{g}$ ) moving down river towards Lake Superior. This occurs even though the total concentration of $\mathrm{MeHg}$ in surface water decreases moving down river. It is possible that the organic carbon associated with the suspended particulate matter increases (or black carbon content changes) when moving down the St. Louis River. However, Manolopoulos et al. (2003) hypothesized that this increase in particulate $\mathrm{MeHg}$ was the result of the 
bioaccumulation of $\mathrm{Hg}$ in particulate plankton. As turbidity decreases downriver into Lake Superior, the phytoplankton activity most likely increases (due to increased availability of light). This illustrates a possible limitation of partitioning coefficients to estimate $\mathrm{Hg}$ concentrations in particulate and dissolved phases of the water column (even if expressed as organic carbon partitioning).

In this WASP model, none of the silt/fines, sand, or organic matter associated with silt/fines were assigned as dissolved-(remaining in suspension)-in-the-sediment porewater. This was done because solids are typically filtered out (colloid straining) from porewater upon any porewater movement. If groundwater advection were modeled in the WASP model, and the DOC in the groundwater were associated with contaminant migration, the dissolved $\mathrm{Hg}$ settings were expected to account for this (the partitioning coefficients used are between the solid and total dissolved water phases). However, to account for migration of settleable particulates in porewater, the fractions of dissolved silt/fines and associated organic matter may need to be set to something greater than zero. In addition, further work using the WASP model could look at different thicknesses of the mixed sediment layer and methylation layer. There is uncertainty related to the thickness of these layers as it will likely vary across the site.

Unlike the HERMES model, the surface water hydraulic flows in WASP were specifically reduced for the restoration scenario. HERMES actually had a slightly lower hydraulic residence time in the cove for the restoration scenario, which implies higher flows. Higher flows to the model domain will cause the sediment bed to influence the surface water less, because the $\mathrm{Hg}$ that enters the surface water from the sediment takes less time to "flush out." Despite this, surface water $\mathrm{Hg}$ concentrations were fairly level in the WASP model restored scenario, and also remained relatively similar in the HERMES model. Hydraulic residence time is discussed more in regards to the SERAFM model below.

The WLSSD discharge to the model boundary was not included in this WASP simulation. The changes in surface water $\mathrm{Hg}$ concentrations caused by the WLSSD are also not considered. WASP could be constructed to be more complex (e.g., a two-box model), where the WLSSD effluent enters an outer box, with the cove being an inner box. The model boundary (estuary) could then be adjacent to the outer box. The inputs of Miller and 
Coffee Creeks could also be designed in a more complex WASP model. The WASP model could incorporate seasonal changes in flow from the creeks. Considerable more complexity can be incorporated in the WASP model, while HERMES and SERAFM are limited to more simplistic modeling scenarios. 


\section{SERAFM Model}

The SERAFM model is a process-based, steady-state, mass-balance model (Knightes 2008). Therefore, it is unable to incorporate seasonal temporal changes. There is also a SERAFM LITE version of the model, which is slightly simpler and does not provide as many output scenarios (for contaminated sediment). "Running" SERAFM is nearly instantaneous (Brown et al. 2007). This model has output for $\mathrm{Hg}$ concentrations in surface water and sediment, and also keeps track of $\mathrm{Hg}$ bioaccumulation in phytoplankton solids, zooplankton solids, and fish, using bioaccumulation factors (Knightes 2008). Knightes (2008) describes the SERAFM model in detail. The model was originally designed for lakes in the eastern U.S., but it has also been applied to flowing systems and various restoration scenarios (Brown et al. 2007). The model has more inputs than HERMES, but less than WASP. SERAFM has many default values (or built-in estimation methods) available, and the model is designed to be used in that way until more information can be obtained. The entire model is included in 13 functional worksheets in Microsoft Excel that include partitioning algorithms, $\mathrm{Hg}$ transformations, and watershed functions (Brown et al. 2007). The watershed component was specifically utilized for this analysis. The watershed associated with the cove initially (no-action scenario) is the St. Louis River watershed; but after restoration, the Miller Creek watershed might be more relevant to influencing the cove. This is due to volume changes and the growth of aquatic plants that will limit hydraulic mixing from the estuary. SERAFM may also be used in such a way that the influence of the watersheds are minimized by setting the watershed area and precipitation rate to minimal values (Brown et al. 2007).

Some of the SERAFM model inputs were kept constant for both a "noaction" and "restoration" scenario (as with HERMES), and are listed in Table 7. The model requires an initial statement of whether the site is east or west of the Mississippi River. Though the site is east of the Mississippi River at its latitude, the site is west of the lower Mississippi River. Depending on how SERAFM incorporates this information (probably relates to atmospheric $\mathrm{Hg}$ deposition), it may be worth examining the site as both east and west of the Mississippi River.

There was no report of the percentage of the watersheds that had Hgcontaminated soil. It is known that there are contaminated sites in the St. 
Louis River watershed; however, until the details of this can be obtained, the Hg contaminated soils were assumed to be zero. The model domain area was set the same as in the previous models. Though the DOC fluctuates, $20 \mathrm{mg} / \mathrm{L}$ is a reasonable estimate for the estuary as previously described. Color (as PtCo) was measured by Host et al. (2012). This value may fluctuate and be influenced by aquatic plant growth. Future work could examine color (as PtCo) more closely. A St. Louis River AOC Stage II Remedial Action Plan (RAP) (2013) reported the estuary as being eutrophic in the late 1970s. The WLSSD has been upgraded since then, which has shifted the trophic status of the estuary. Though it is difficult to place the estuary in a trophic status, "mesotrophic" was selected as most appropriate. With the inputs on color entered into SERAFM, the model has an internal calculation that sets the trophic status. The internal calculation produced in SERAFM returns the trophic status as "dystrophic." In the "Parameters" tab the trophic level was manually set as mesotrophic ("2"). Again, as the site is restored, trophic status may be worth changing between the two scenarios.

As in the WASP model, demethylation was assumed to be 0.0002 and 0.00002 day $^{-1}$ in the water and sediment, respectively (RTI International and URS 2013). A typical value for methylation was selected for the sediments $\left(0.001\right.$ day $\left.^{-1}\right)$, while methylation was set to "o" in the water column, as in the WASP model. The SERAFM model needs to capture all of the sediment methylation processes (including redox gradients) in this $1^{\text {st }}$ order methylation rate. In SERAFM, the hypolimnion is aerobic, and the methylation in this layer is automatically calculated to be 0.001 day $^{-1}$. This automatic calculation was replaced with a value of zero.

Table 7. Constant input values for SERAFM - held constant for both scenarios.

\begin{tabular}{|l|l|l|l|}
\hline Input & Value & Units & Reference \\
\hline East or West of Mississippi River & East & - & Google Maps \\
\hline $\begin{array}{l}\text { Percent of Watershed } \\
\text { Contaminated with Mercury }\end{array}$ & 0 & $\%$ & Assumption based on limited information \\
\hline Model Domain Area & 426,000 & $\mathrm{~m}^{2}$ & Site Maps, Detroit District, 2013 \\
\hline Hypolimnion Depth & 0.0001 & $\mathrm{~m}$ & Brown et al. 2007 (flowing system) \\
\hline Anoxic Hypolimnion? & No & - & Brown et al. 2007 (flowing system) \\
\hline pH & 8.1 & - & Babiarz et al. 2012 \\
\hline Water Temperature & 10.5 & ${ }^{\circ} \mathrm{C}$ & Babiarz et al. 2012 \\
\hline Air Temperature & 15 & ${ }^{\circ} \mathrm{C}$ & NOAA, 1998 \\
\hline
\end{tabular}




\begin{tabular}{|l|l|l|l|}
\hline Input & Value & Units & Reference \\
\hline DOC & 20 & $\mathrm{mg} / \mathrm{L}$ & $\begin{array}{l}\text { Berndt \&Bavin, 2012; Beck \& Johnson, } \\
2014\end{array}$ \\
\hline Color & 232 & PtCo & Host et al. 2012 \\
\hline Trophic Status & Mesotrophic & - & $\begin{array}{l}\text { Assumption based on St. Louis River AOC } \\
\text { Stage II RAP and changes since the 1970s }\end{array}$ \\
\hline Methylation Rate in water & 0 & day $^{-1}$ & Assumption based on Ullrich et al. 2001 \\
\hline Methylation Rate in sediment & $1.00 \mathrm{E}-03$ & day- $^{-1}$ & Assumption based on Drott et al. 2007 \\
\hline Demethylation Rate in water & $2.00 \mathrm{E}-04$ & day $^{-1}$ & RTI International and URS, 2013 \\
\hline Demethylation Rate in sediment & $2.00 \mathrm{E}-05$ & day $^{-1}$ & RTI International and URS, 2013 \\
\hline
\end{tabular}

Other parameters in SERAFM were varied between "no-action" and "restoration" scenarios, and are listed in Table 8. Watershed areas for the St. Louis River (Hoffman et al. 2012) and Miller and Coffee Creek (Fitspatrick et al. 2006) have been reported. However, in the case of the no-action scenario, using the watershed area for the entire St. Louis River (SLR) when modeling the cove resulted in unrealistically high $\mathrm{Hg}$ concentrations. This is because SERAFM was feeding the run-off from the entire SLR to the cove. Instead, the watershed area for Miller Creek was used for the no-action scenario, as well as the restoration scenario, but for the no-action scenario, the land-use types for the SLR were applied. In this way, the watersheds were equally weighted in the case of the two scenarios. For the SLR estuary, Angradi et al. (2013) reported that only 2\% of the watershed was developed, which was considered impervious.

Depending on the source, the percentage of wetlands in the SLR watershed varied considerably (a value of $32.2 \%$ was selected from Babiarz et al. 2012). The important distinction is that the percentage of wetlands in the SLR watershed is significantly greater than in the Miller Creek watershed. The remaining $66 \%$ of the SLR watershed is mostly forested. For lack of better information, it was assumed that this should be split evenly between riparian and upland zones (33\% each). For the Miller Creek watershed, Fitspatrick et al., (2006) reported 60\% urban (impervious), 1\% wetland, 10\% upland (grasslands included), and 29\% lowland (assumed to be riparian). The Coffee Creek watershed is fairly similar to the Miller Creek watershed, but is much smaller in area. Therefore, the Miller Creek watershed was used to determine overall land use. The model domain depth was set the same as in the WASP model. However, since SERAFM was originally designed for lakes, it has a hypolimnion layer, which was minimized to $0.1 \mathrm{~mm}$ (Brown et al. 2007) because the estuary is a nonstratified environment. 
Table 8. SERAFM inputs that were altered between no-action and restoration scenarios.

\begin{tabular}{|c|c|c|c|c|}
\hline Input & $\begin{array}{l}\text { Value } \\
\text { (No Action) }\end{array}$ & $\begin{array}{l}\text { Value } \\
\text { (Restoration) }\end{array}$ & Units & Reference \\
\hline $\begin{array}{l}\text { Watershed } \\
\text { Characterization }\end{array}$ & $\begin{array}{l}\text { St. Louis } \\
\text { River } \\
\text { Watershed }\end{array}$ & $\begin{array}{l}\text { Miller Creek } \\
\text { Watershed }\end{array}$ & - & $\begin{array}{l}\text { Assumption based on } \\
\text { knowledge of changes due to } \\
\text { restoration }\end{array}$ \\
\hline Watershed Area & $\begin{array}{l}1.1 \mathrm{E}+10 \\
(2.8 \mathrm{E}+7 \\
\text { used })\end{array}$ & $2.8 \mathrm{E}+7$ & $m^{2}$ & $\begin{array}{l}\text { Hoffman et al. } 2012 \\
\text { Fitspatrick et al. } 2006\end{array}$ \\
\hline $\begin{array}{l}\text { Percent } \\
\text { Impervious }\end{array}$ & 2 & 60 & $\%$ & $\begin{array}{l}\text { Angradi et al. 2013; Fitspatrick } \\
\text { et al. } 2006\end{array}$ \\
\hline Percent Wetland & 32.2 & 1 & $\%$ & $\begin{array}{l}\text { Babiarz et al. 2012; Fitspatrick } \\
\text { et al. } 2006\end{array}$ \\
\hline Percent Riparian & 32.9 & 29 & $\%$ & $\begin{array}{l}\text { USDA SLR Rapid Watershed } \\
\text { Assessment, Fitspatrick et al. } \\
2006\end{array}$ \\
\hline $\begin{array}{l}\text { Surface Water } \\
\text { Depth }\end{array}$ & 2 & 0.3 & $\mathrm{~m}$ & $\begin{array}{l}\text { Site Designs, Detroit District, } \\
2013\end{array}$ \\
\hline Residence Time & $9 \mathrm{E}-4$ & 0.005 & years & $\begin{array}{l}\text { Petticrew and Kalff, 1992, Shi } \\
\text { et al. 2013, Kleeberg } 2010\end{array}$ \\
\hline$\left[\mathrm{Hg}^{0}\right]$ in inflow & 3.1E-07 & $2.2 \mathrm{E}-07$ & $\mathrm{~g} / \mathrm{m}^{3}$ & see WASP; Ruzycki et al. 2011 \\
\hline$\left[\mathrm{Hg}^{2+}\right]$ in inflow & $1.72 \mathrm{E}-06$ & $1.24 \mathrm{E}-06$ & $\mathrm{~g} / \mathrm{m}^{3}$ & see WASP, Ruzycki et al. 2011 \\
\hline [MeHg] in inflow & 7.0E-08 & 5.0E-08 & $\mathrm{g} / \mathrm{m}^{3}$ & see WASP, Ruzycki et al. 2011 \\
\hline $\begin{array}{l}\text { Total Hg in } \\
\text { Sediment }\end{array}$ & 0.23 & 0.08 & $\mu \mathrm{g} / \mathrm{g}$ & $\begin{array}{l}\text { see WASP section (not used } \\
\text { with SERAFM LITE) }\end{array}$ \\
\hline
\end{tabular}

Residence times were set based on the HERMES model for the no-action scenario. For the restoration scenario, the residence time was based on the volume $\left(127,800 \mathrm{~m}^{3}\right)$ and assumed median flow from Miller Creek $(0.8 \mathrm{~m} 3 / \mathrm{s})$, which provide an average value of 0.005 years. Suspended material monitoring has been used as a surrogate measure of $\mathrm{Hg}$ in Western Lake Superior watersheds (Ruzycki et al. 2011). For the restoration scenario, the total surface water $\mathrm{Hg}$ from Miller Creek was estimated from a relationship (log total $\mathrm{Hg}=0.5(\log$ TSS $)+0.18)$ between total Hg and TSS in similar streams (Ruzycki et al. 2011). A value of $1 \mathrm{mg} / \mathrm{L}$ was used for Miller Creek TSS (Anderson et al. 2000), yielding a total Hg estimate of 1.51 $\mathrm{ng} / \mathrm{L}$. The different forms of $\mathrm{Hg}$ were determined using the same ratios of $\mathrm{Hg}$ in the initial total surface water of the WASP model $\left(14.7 \% \mathrm{Hg}^{\circ}, 81.9 \%\right.$ $\mathrm{Hg}^{2+}$, and 3.3\% MeHg). Future work should seek a measurement of the fraction of the different forms of $\mathrm{Hg}$ in the creek surface water. 
In the sediment, SERAFM inputs only require a total $\mathrm{Hg}$ level in the bulk sediments (in SERAFM LITE, no sediment Hg concentrations are required (similar to HERMES)). There were many sources of information on total $\mathrm{Hg}$ in the bulk sediment of the cove. The value $(0.23 \mu \mathrm{g} / \mathrm{g})$ used in WASP was applied to the no-action scenario in SERAFM. For the restoration scenario, the total $\mathrm{Hg}$ in the bulk Kingsbury sediment was the best estimate for the surficial sediments $(0.08 \mu \mathrm{g} / \mathrm{g})$.

\section{SERAFM Results and Discussion}

The SERAFM model results show steady-state conditions. It also input known changes in bulk sediment concentrations and possible changes in surface water supply (watershed shifting). Output surface water $\mathrm{MeHg}$ concentrations increase relative to the input inflow concentrations for both scenarios. It is also clear that restoration increases surface water $\mathrm{MeHg}$ and total $\mathrm{Hg}$ concentrations relative to the no-action scenario (Table 9). This occurred despite the fact that the watershed characteristics changed in the restored scenario to one with significantly less wetlands, and the inflow $\mathrm{Hg}$ concentrations were reduced. This may be due to the longer residence time of the restored scenario (relative to the no-action scenario and relative to the other models), and thus a stronger influence on surface water $\mathrm{Hg}$ from the sediment. If the restoration scenario hydraulic residence time is changed back to that for a no-action scenario (leaving all other inputs the same), the surface water total $\mathrm{Hg}$ concentrations indeed drop from around $7 \mathrm{ng} / \mathrm{L}$ to less than $4 \mathrm{ng} / \mathrm{L}$. In the bulk sediment, the total $\mathrm{Hg}$ remained constant between the input values and the output values for both scenarios. The $\mathrm{MeHg}$ and total $\mathrm{Hg}$ sediment concentrations decreased in the restoration scenario because the bulk phase total Hg concentrations were set to be the lower levels of the placed Kingsbury Bay "biomedium" sediment. As the HERMES model was implemented here, no attempt was made to directly input these lower levels. The WASP model used placed dredged material from the navigation channel, rather than Kingsbury Bay sediment, because more detailed information (the $\mathrm{MeHg}$ concentrations) was available for that material. In SERAFM, the bulk phase concentrations actually do not change at all from input values. In the porewater, $\mathrm{MeHg}$ concentrations greatly decrease and total $\mathrm{Hg}$ concentrations also decrease. This occurred even though there was no explicit input to change the sediment TOC in SERAFM. Further work should explore which input parameters had the greatest influence on sediment porewater concentrations in the SERAFM model. Explicitly changing the sediment TOC in the SERAFM model to account for plant growth (as was done in the HERMES model) may also be worth exploring. 
Table 9. SERAFM steady-state results: MeHg and total Hg concentrations in water and sediment.

\begin{tabular}{|l|c|c|c|c|c|c|}
\hline \multirow{2}{*}{$\begin{array}{l}\text { Matrix or Media } \\
\text { (units) }\end{array}$} & \multicolumn{2}{l|}{ MeHg } & \multirow{2}{*}{ \% Increase } & \multicolumn{2}{l|}{ Total Hg } & \% Increase \\
\cline { 2 - 6 } & No Action & Restoration & & No Action & Restoration & $241 \%$ \\
\hline $\begin{array}{l}\text { Total Surface } \\
\text { Water (ng/L) }\end{array}$ & 0.10 & 0.27 & $170 \%$ & 2.23 & 7.61 & $127 \%$ \\
\hline $\begin{array}{l}\text { Dissolved } \\
\text { Surface Water } \\
\text { (ng/L) }\end{array}$ & 0.09 & 0.22 & $144 \%$ & 2.13 & 6.97 & $-188 \%$ \\
\hline $\begin{array}{l}\text { Bulk Sediment } \\
\text { (ng/g) }\end{array}$ & 210 & 80 & $-163 \%$ & 230 & 80 & $-164 \%$ \\
\hline $\begin{array}{l}\text { Sediment } \\
\text { Porewater (ng/L) }\end{array}$ & 7.78 & 0.82 & $-849 \%$ & 8.23 & 2.26 & \\
\hline
\end{tabular}

Default partitioning coefficients of $\mathrm{Hg}$ to the sediment were applied in the SERAFM model. Future work may explore the implementation of sitespecific partitioning ratios. However, the reason for not setting partitioning to initial site measured values was that these ratios may be very different in the future restored site. The default adjustments may or may not capture these changes. This is something that could be examined as the pilot project monitoring continues.

Similar to the partitioning ratios and sediment TOC, the suspended particulate matter (or TSS) and resuspension rate were also not explicitly modified in the SERAFM model. In this way, SERAFM was run more like the WASP model than the HERMES model. Future work should look into how SERAFM automatically adjusts these values.

Changing the watershed that supplied surface water to the "model domain" was a very different approach than that taken for the other models (HERMES and WASP). The HERMES model contains some precalculation steps for utilizing the watershed area (and \% wetlands in the watershed) to calculate $\mathrm{Hg}$ inflow concentration. This was not implemented in HERMES, but instead, the measured $\mathrm{Hg}$ (2 ng/L) in the SLR estuary was used. WASP can also include detailed inputs to represent different watershed contributions and can be connected to watershed models (though this was not done here). Future work could explore the incorporation of watershed changes in the HERMES and WASP models. In SERAFM, the effect of the watershed can be de-emphasized by setting the watershed area equal to a very small value (i.e., $1 \mathrm{~m}^{2}$ ) (Brown et al. 2007). Future work may include focusing on just the waterbody (instead of the watershed and waterbody) aspects of SERAFM. 
The rates of reaction (methylation and demethylation) were not changed between model scenarios (for WASP or SERAFM), but they may not be accurate. For example, the ratio of MeHg to total $\mathrm{Hg}$ in SERAFM was 1 in the restored scenario. This unrealistically high value indicates that perhaps the methylation/demethylation $(\mathrm{m} / \mathrm{d})$ ratio was too high in the sediments. The rates could be adjusted until more realistic MeHg to total $\mathrm{Hg}$ ratios are achieved (model calibration). Previously used values of the rates of reaction were assumed, and the effects of more understood inputs in the model were varied between scenarios. Future modeling efforts that focus on a particular model (HERMES, WASP, or SERAFM) will need to test the uncertainty (or range) of the input values (e.g., Monte Carlo method).

Finally, the SERAFM model provides some bioaccumulation outputs using default bioaccumulation factors. For the no-action scenario, trophic level 3 and 4 fish reached tissue concentrations of 50 and $200 \mathrm{ng} / \mathrm{g}$ at steadystate, respectively. For the restoration scenario, trophic level 3 and 4 fish reached tissue concentrations of 120 and $510 \mathrm{ng} / \mathrm{g}$ at steady-state, respectively. This exceeds the MPCA fish tissue $\mathrm{Hg}$ standard of $200 \mathrm{ng} / \mathrm{g}$. The bioaccumulation results may have little usefulness until the model is better calibrated and tested, but eventually this additional SERAFM output could be useful. 


\section{Summary}

The three models used in this study (HERMES, WASP, and SERAFM) were applied very differently and, in some ways, comparing them in Table 10 is inappropriate; where o indicates little change, + indicates an increase, and - indicates a decrease for restoration compared to no action. Double symbols (++ or --) indicate larger increases or decreases. The models were applied in different ways to explore possible strengths of each model, rather than to make direct comparisons between models. Nevertheless, the HERMES model, which was most explicitly changed to account for the changes caused by aquatic plant growth, showed the greatest increases in sediment MeHg. The exact changes of $\mathrm{Hg}$ concentrations in the placed sediment were not directly input in the HERMES model. The WASP model, which was most likely simulating a situation where dredged material is placed and aquatic plants do not grow, showed the least overall changes in surface water and sediment MeHg. It is possible that plants will not grow at the site. However, it may also be worthwhile to force more changes on the WASP model that would be caused by plant growth. WASP incorporated the most detail in terms of initial conditions at the site, and also has the potential to incorporate much more detail than was conducted here (i.e., WLSSD effluent, multiple boxes, temporal seasonal changes, plant evapotranspiration). The SERAFM model, which had the least "flushing" of the surface water in the restored scenario, showed the greatest increases in surface water $\mathrm{MeHg}$ (despite entered reductions in sediment $\mathrm{Hg}$ ). A proper comparison between these models would need to have identical exchange rates of the surface water set in all of the models.

This study focused on the usefulness of each of the models separately for their ability to predict long-term MeHg changes in sediment, sediment porewater, surface water (including suspended particulates), and dissolved-in-surface water after the creation of shallow water habitat, relative to a "no-action" scenario at the site. The hydraulic residence time of the surface water may be a highly sensitive model parameter with a high degree of uncertainty (especially for the restoration scenario). Further work is necessary before these models can inform management decisions. This report begins to lay the groundwork for such an effort. 
Table 10. Overall comparisons of MeHg concentrations between models.

\begin{tabular}{|l|c|c|c|c|}
\hline \multirow{2}{*}{\multicolumn{1}{|c|}{ Model }} & \multicolumn{4}{|c|}{ MeHg } \\
\cline { 2 - 5 } & \multicolumn{2}{|c|}{ Surface Water } & \multicolumn{2}{c|}{ Sediment (or Mixed Layer) } \\
\cline { 2 - 5 } & Total & Dissolved & Bulk & Porewater \\
\hline HERMES & 0 & + & ++ & ++ \\
\hline WASP & 0 & 0 & 0 & 0 \\
\hline SERAFM & ++ & ++ & -- & - \\
\hline
\end{tabular}




\section{References}

Anderson, J., T. Estabrooks, and J. McDonnel.200o. Duluth Metropolitan Area Streams Snowmelt Runoff Study. Minnesota Pollution Control Agency.

Angradi, T. R., M. S. Pearson, D. W. Bolgrien, B. J. Bellinger, M. A. Starry, and C. Reschke. 2013. Predicting submerged aquatic vegetation cover and occurrence in a Lake Superior estuary. J. Great Lakes Res. 39:536-546.

Babiarz, C., S. Hoffman, A. Wieben, J. Hurley, A. Andren, M. Shafer, and D. Armstrong. 2012. Watershed and discharge influences on the phase distribution and tributary loading of total mercury and methylmercury into Lake Superior. Environ. Pollut. 161:299-310.

Bahnick D. A., and T. P. Markee. 1985. Occurrence and transport of organic microcontaminants in the Duluth-Superior Harbor. Journal of Great Lakes Research. 11(2): 143-155.

Baptist, M. J. 2003. A flume experiment on sediment transport with flexible submersed vegetation. International workshop on riparian forest vegetated channels: hydraulic, morphological and ecological aspects. Treno, Italy.

Beck, B. F. and N. W. Johnson. 2014. Geochemical factors influencing the production and transport of methylmercury in St. Louis River Estuary sediment. Applied Geochemistry. 51:44-54.

Beck B. F. 2013. Geochemical controls on production and transport of methylmercury in the St. Louis River Estuary. MS Thesis, Univ. of Minnesota.

Berndt M. E., and T. K. Bavin. 2012. Methylmercury and dissolved organic carbon relationships in a wetland-rich watershed impacted by elevated sulfate from mining. Environmental Pollution. 161: 321-327.

Best, E. P. H., A. M. Teeter, K. Landwehr, W. F. James, and S. K. Nair. 2008. Restoration options for potential persistence of submerged aquatic vegetation: combining ecological, hydrodynamic and sediment transport modeling. Freshwater Biology $53: 814-826$.

Boyer, J. M.; S. C. Chapra, C. E. Ruiz, and M. S. Dortch. 1994. RECOVERY, a mathematical model to predict the temporal response of surface water to contaminated sediments. Technical Report W-94-4. Vicksburg, MS: U.S. Army Engineer Waterways Experiment Station.

Brown, S.; L. Saito, C. Knightes, M. Gustin. 2007. Calibration and Evaluation of a Mercury Model for a Western Stream and Constructed Wetland. Water Air Soil Pollut. 182:275-290.

Caraco, N., J. Cole, S. Findlay, C. Wigand. 2006. Vascular Plants as Engineers of Oxygen in Aquatic Systems. BioScience 56(3):219-225.

Carpenter, S. R. and D. M. Lodge. 1986. Effects of Submersed Macrophytes on Ecosystem Processes. Aquatic Botany 341-370. 
Chapra, S. C. 1997. Surface Water-Quality Modeling. New York: McGraw-Hill.

Cosio, C.; R. Flück, N. Regier, V. I. Slaveykova. 2014. Effects of macrophytes on the fate of mercury in aquatic systems. Environ. Tox. Chem. 33(6): 1225-1237.

Czuba, M. and D. C. Mortimer. 1980. Stability of methylmercury and inorganic mercury in aquatic plants (Elodea densa). Can. J. Bot. 58: 316-320.

Davis, J. M.; T. W. Collett, D. L. Villeneuve, J. E. Cavallin, Q. Teng, K. M. Jensen, M. D. Kahl, J. M. Mayasich, G. T. Ankley, D. R. Ekman. 2013. Field-Based Approach for Assessing the Impact of Treated Pulp and Paper Mill Effluent and Endogenous Metabolites of Fathead Minnows (Pimephales promelas). Environ. Sci. Technol. 47: 10628-10636.

Dove A., B. Hill, P. Klawunn, J. Waltho, S. Backus, R. C. McCrea. 2012. Spatial distribution and trends of total mercury in waters of the Great Lakes and connecting channels using an improved sampling technique. Environmental Pollution. 161: 328-334.

Drott, A.; L. Lambertsson, E. Björn, and U. Skyllberg. Importance of Dissolved Neutral Hg Sulfides for Methylmercury Production in Contaminated Sediments. Environ. Sci. Technol. 2007 (41): 2270-2276.

Eichmiller, J. J. R. E. Hicks, and M. J. Sadowsky. 2013. Distribution of Genetic Markers of Fecal Pollution on a Freshwater Sandy Shoreline in Proximity to Wastewater Effluent. Environ. Sci. Technol. 47: 3395-3402.

Eikenberry, B. C. S.; K. Riva-Murray, C. D. Knightes, C. A. Journey, L. C. Chasar, M. E. Brigham, and P. M. Bradley. 2015. Optimizing fish sampling for fish-mercury bioaccumulation factors. Chemosphere 135: 467-473.

Erdmann J. B., H. G. Stefan and P. L. Brezonik. 1994. Analysis of Wind-And ShipInduced Sediment Resuspension in Duluth-Superior Harbor. Water Resources Bulletin. 30(6): 1043-1053.

Erickson, T. O.; W. R. Herb, and H. G. Stefan. 2010. Streamflow modeling of Miller Creek. Project Report No. 536. Duluth, MN: University of Minnesota, St. Anthony Falls Laboratory.

Ethier, A. L. M., D. R. S. Lean, A. M. Scheuhammer, T. Bodek, K. Sosso-Kolle. 2010. Predicting Mercury Concentrations and Fluxes in the Water Column and Sediment of Lakes with a Limited Dataset. Env. Tox. Chem. 29(7):1457-1465.

Ethier, A. 2009. HERMES: A modeling tool for predicting mercury concentrations and fluxes in lakes. PhD diss., University of Ottawa.

Fitspatrick, F. A., M. C. Peppler, M. M. DePhilip, and K. E. Lee. 2006. Geomorphic Characteristics and Classification of Duluth-area streams, MN. USGS Scientific Investigations Report 5029.

Gilmour, C. C., G. S. Riedel, G. Riedel, S. Kwon, R. Landis, S. S. Brown, C. A. Menzie, U. Ghosh. 2013. Activated Carbon Mitigates Mercury and Methylmercury Bioavailability in Contaminated Sediments. Env. Sci. Technol. 47(22): 1300113010. 
Glass, G. E., and J. A. Sorensen, Six-Year Trend (1990-1995) of Wet Mercury Deposition in the Upper Midwest, U.S.A. Environ. Sci. Technol. 1999 (33): 3303-3312.

Glass, G. E., J. A. Sorensen, K. W. Schmidt, and G. R. Rapp. 1990. New Source Identification of Mercury Contamination in the Great Lakes. Environ. Sci. Technol. 24: 1059-1069.

Göthberg, A. and M. Greger. 2006. Formation of methylmercury in an aquatic macrophyte. Chemosphere 65: 2096-2105.

Haag, R. W., and P. R. Gorham. 1977. Effects of Thermal Effluent on Standing Crop and Net Production of Elodea Canadensis and other Submersed Macrophytes in Lake Wabemum, Alberta. J. of Applied Ecology. 14(3): 835-851.

Hall, B. D., H. Manolopoulos, J. P. Hurley, J. J. Schauer, V. L. St. Louis, D. Kenski, J. Graydon, C. L. Babiarz, L. B. Cleckner, and G. J. Keeler. Methyl and total mercury in precipitation in the Great Lakes region. Atmospheric Environment 2005(39): 7557-7569.

Hansen, D. L., S. Ishii, M. J. Sadowsky, R. E. Hicks. 2011. Waterfowl Abundance Does Not Predict the Dominant Avian Source of Beach Escherichia coli. J. Environ Qual. 40: 1924-1931.

Hensley, R. N. 2012. Effects of wastewater disinfection on triclosan and detection of a hydroxylated polybrominated diphenyl ether in wastewater effluent. MS thesis, University of Minnesota.

Hoffman, J. C.; J. R. Kelly, G. S. Peterson, A. M. Cotter, M. A. Starry, M. E. Sierszen. 2012. Using $\delta^{15} \mathrm{~N}$ in Fish Larvae as an Indicator of Watershed Sources of Anthropogenic Nitrogen: Responses at Multiple Spatial Scales. Estuaries and Coasts 35: 1453-1467.

Holcová, V. et al. 2009. The effect of macrophytes on retention times in a constructed wetland for wastewater treatment. International Journal of Sustainable Development \& World Ecology 16(5): 362-367.

Horppila J., and L. Nurminen 2003. Effects of submerged macrophytes on sediment resuspension and internal phosphorous loading in Lake Hiidenvesi (southern Finland). Water Research 37: 4468-4774.

Host, G., P. Meysembourg, C. Reschke, V. Brady, G. Niemi, A. Bracey, L. Johnson, M. James, J. Austin, E. Buttermore. 2013. An ecological design for the $21^{\text {st }}$ avenue west remediation-to-restoration project. Contracted by: US Fish and Wildlife Service. NRRI/TR-2013/24.

Host, G., C. Reschke, V. Brady, D. Breneman, J. Dumke, G. Niemi, J. Austin, M. James, L. Johnson. 2012. 21 $1^{\text {st }}$ Avenue west remediation to restoration project: Biological surveys and hydrodynamic modeling results. Contracted by: US Fish and Wildlife Service. NRRI/TR-2012/54.

Hsu-Kim, H.; K. H. Kucharzyk, T. Zhang, M. A. Deshusses. Mechanisms regulating mechanisms regulating mercury bioavailability for methylating microorganisms in aquatic environment: A critical review. Environ. Sci. Technol. 2013(47): 24412456. 
Jarvis, J. C. and K. A. Moore. 2008. Influence of environmental factors on Vallisneria Americana seed germination. Aquatic Botany 88: 283-294.

Jaynes, M. L. and S. R. Carpenter. 1986. Effects of Vascular and Nonvascular Macrophytes on Sediment Redox and Solute Dynamics. Ecology 67(4): 875-882.

Jonsson, S.; U. Skyllberg, and E. Bjorn. Substantial emission of gaseous monomethylmercury from contaminated water-sediment microcosms. Environ. Sci. Technol. 2010(44): 278-283.

Kahl et al. 2014. An Inexpensive, Temporally Integrated System for Monitoring Occurrence and Biological Effects of Aquatic Contaminants in the Field. Environ. Toxicol. Chem. 33(7): 1584-1595.

Kleeberg A., J. Kohler, T. Sukhodolova, A. Sukhodeolov. 2010. Effects of aquatic macrophytes on organic matter deposition, resuspension and phosphorus entrainment in a lowland river. Freshwater Biology 55: 326-345.

Knightes, C. D. 2008. Development and test application of a screening-level mercury fate model and tool for evaluating wildlife exposure risk for surface waters with mercury-contaminated sediments (SERAFM). Environmental Modeling \& Software 23: 495-510.

Kreitinger, J. P. 2015. Duluth Superior Harbor 21st Ave. West Pilot Project - 2014 Turbidity Monitoring. Memorandum for Record. Prepared by the U.S. Army Engineer Research and Development Center Environmental Laboratory for the USACE Detroit District.

Lacoul, P. and B. Freedman. 2006. Environmental Influences on Aquatic Plants in Freshwater Ecosystems. Environ. Rev. 14: 89-136.

Lafabrie, C.; K. M. Major, C. S. Major, J. Cebrián. 2011. Arsenic and mercury bioaccumulation in the aquatic plant, Vallisneria neotropicalis. Chemosphere 82: 1393-1400.

LaPara, T. M.; T. R. Burch, P. J. McNamara, D. T. Tan, M. Yan, J. J. Eichmiller. 2011. Tertiary-Treated Municipal Wastewater is a Significant Point Source of Antibiotic Resistance Genes into Duluth-Superior Harbor. Environ. Sci. Technol. 45: 95439549 .

LimnoTech. 2013. St. Louis River Area of Concern Sediment Characterization: Final Report. Prepared for: MPCA. Dashboard Info. pg. 81. July $11^{\text {th }}, 2013$.

Madsen, J. D. P. A. Chambers, W. F. James, E.W. Koch, D. F. Westlake, 2001. The Interaction between Water Movement, Sediment Dynamics and Submersed Macrophytes. Hydrobiologia 444: 71-84.

Manolopoulos, H.; J. P. Hurley, C. L. Babiarz, R. C. Back, K. R. Rolfhus. 2003. Riverine mixing zones as regions of enhanced methylmercury bioaccumulation in Lake Superior. J.Phys. IV France. 107:805-808.

Martinovic, D.; J. S. Denny, P. K. Schmieder, G. T. Ankley, P. W. Sorensen. 2008. Temporal Variation in the Estrogenicity of a Sewage Treatment Plant Effluent and Its Biological Significance. Environ. Sci. Technol. 42: 3421-3427. 
Minnesota Pollution Control Agency. 2010. Guidance Manual for Assessing the Quality of Minnesota Surface Waters for Determination of Impairments: 305 (b) Report and 303 (d) List. 2010 Assessment Cycle.

Moore, K. A.; E. C. Shields, J. C. Jarvis. 2010. The Role of Habitat and Herbivory on the Restoration of Tidal Freshwater Submerged Aquatic Vegetation Populations. Restoration Ecology 18(4): 596-604.

NOAA. 1998. National Climate Data Center. http://www.ncdc.noaa.gov/most-populardata\#wind

Nishihara, G. N., and J. D. Ackerman. 2007. The interaction of $\mathrm{CO}_{2}$ concentration and spatial location on $\mathrm{O}_{2}$ flux and mass transport in the freshwater macrophytes Vallisneria spiralis and V. americana. J. of Experimental Biology 210: 522-532.

Petticrew, E. L.; J. Kalff. 1992. Water Flow and Clay Retention in Submerged Macrophyte Beds. Can. J. Fish. Aquat. Sci. 49: 2483-2489.

Richards, C., F. Kutka, and P. Tucker. 1992. A Winter Survey of Fishes in the Vicinity of the WLSSD Sewage Treatment Plant: November, 1991-April, 1992. NRRI/TR92/12.

RTI International and URS Corporation. 2013. St. Louis River Estuary TMDL Project: Preliminary EFDC-WASP Modeling Report. Prepared for: U.S. EPA Region 5, Contract Number: EP-C-08-003.

Ruzycki, E. M., R. P. Axler, J. R. Henneck, N. R Will, G. E. Host. 2011. Estimating mercury concentrations and loads from four western Lake Superior watersheds using continuous in-stream turbidity monitoring. Aquatic Ecosystem Health and Management 14 (4): 422-433.

Rybicki, N. B. and V. Carter, 1986. Effect of Sediment Depth and Sediment Type on the Survival of Vallisneria Americana Michx Grown from Tubers. Aquatic Botany 24: $233-240$.

Schulz, M. and B. Gücker. 2005. Macrophytes Increase Spatial Patchiness of Fuluvial Sedimentary Records and Effect Temporal Particulate Nutrient Storage. Aquatic Geochemistry 11: 89-107.

Shi, J. Z., Y-H. Li, J. M. R. Hughes, M. Zhao. 2013. Hydrologic characteristics of vegetated river flows: A laboratory flume study. Hydrological Sciences Journal 58(5): 1047-1058.

Teeter, A.M.; Johnson, B.H.; Berger, C.; Stelling, G.; Scheffner, N.W.; Garcia, M.H.; Parchure, T.M. 2001. Hydrodynamic and sediment transport modeling with emphasis on shallow-water, vegetated areas (lakes, reservoirs, estuaries, and lagoons). Hydrobiologia 444: 1-23.

Ullrich S. M.; T. W. Tanton, S. A. Abdrashitova. 2001. Mercury in the Aquatic Environment: A Review of the Factors Affecting Methylation. Critical Reviews in Environmental Science and Technology 31(3): 241-293.

USACE Detroit District. 2008. Sediment Investigation. NOAA Quarry Manager. Eo8112C. 11-05-2008. 
USEPA. 2000. Development of a Framework for Evaluating Numerical Sediment Quality Targets and Sediment Contamination in the St. Louis River Area of Concern. EPA 905-R-00-008. December 2000.

USEPA. 2015. Exposure Assessment Models, WASP 7 Course, WASP Mercury Processes. Available Online: http://www2.epa.gov/exposure-assessment-models/wasp7-course (accessed on October $22^{\text {nd }}, 2015$ )

USEPA. 2015b. EPA On-line Tools for Site Assessment Calculation. Ecosystems Research, Athens, GA, Henry's Law Conversions. Available Online: http://www3.epa.gov/ceampubl/learn2model/part-two/onsite/henryslaw.html (accessed on October 22nd, 2015).

Watkins, C. H. and R. S. Hammerschlag. 1984. The Toxicity of Chlorine to a Common Vascular Aquatic Plant. Water Res. 18(8): 1037-1043.

Wigand, C.; J. C. Stevenson, J. C. Cornwell. 1997. Effects of different submersed macrophytes on sediment biogeochemistry. Aquatic Botany 56: 233-244.

Wool, T. A., R. B. Ambrose, J. L. Martin, E. A. Comer. 2001. Water Quality Analysis Simulation Program (WASP), Version 7.3. Draft User's Manual. Atlanta: US Environmental Protection Agency. 


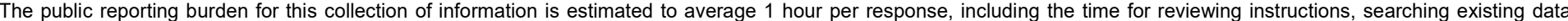

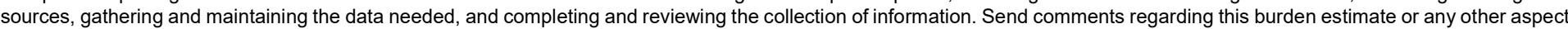

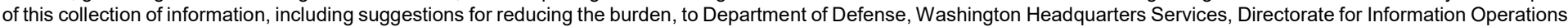

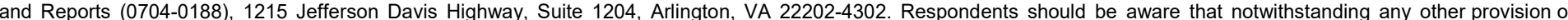
law, no person shall be subject to any penalty for failing to comply with a collection of information if it does not display a currently valid OMB control number.

PLEASE DO NOT RETURN YOUR FORM TO THE ABOVE ADDRESS.

\begin{tabular}{l|l|l}
\hline $\begin{array}{l}\text { 1. REPORT DATE } \\
\text { November } 2017\end{array}$ & $\begin{array}{l}\text { 2. REPORT TYPE } \\
\text { Final }\end{array}$ & 3. DATES COVERED (FrOm - To) \\
\hline
\end{tabular}

\section{TITLE AND SUBTITLE}

Methylmercury Screening Models for Surface Water Habitat Restoration: A Case Study in Duluth-Superior Harbor 5a. CONTRACT NUMBER

5b. GRANT NUMBER

5c. PROGRAM ELEMENT NUMBER

5d. PROJECT NUMBER

5e. TASK NUMBER

5f. WORK UNIT NUMBER

8. PERFORMING ORGANIZATION REPORT NUMBER

ERDC/EL TR-17-19

10. SPONSOR/MONITOR'S ACRONYM(S) DIG, EWN

11. SPONSOR/MONITOR'S REPORT NUMBER(S) NOT APPLICABLE TO EVERY REPORT.

Environmental Laboratory (EL)
3909 Halls Ferry Road Vicksburg, MS 39180-6199

12. DISTRIBUTION/AVAILABILITY STATEMENT

Approved for public release; distribution is unlimited.

\section{SUPPLEMENTARY NOTES}

\section{ABSTRACT}

The placement of dredged material for creating vegetated shallow water aquatic habitat is being assessed for changes in long-term bioavailability of mercury $(\mathrm{Hg})$ to wildlife and humans. The three models used in this study (HERMES, WASP, and SERAFM) were applied in different ways to explore the possible strengths of each model, rather than to make direct comparisons between models. The HERMES model, which was most explicitly changed to account for aquatic plant growth, showed the greatest increases in sediment methylmercury (MeHg). The WASP model, which was most likely simulating a situation where dredged material is placed and aquatic plants do not grow, showed the least overall changes in surface water and sediment MeHg. The SERAFM model, which had the least "flushing" of the surface water in the restored scenario, showed the greatest increases in surface water $\mathrm{MeHg}$ (despite entered reductions in sediment $\mathrm{Hg}$ ). This study focused on the usefulness of each of the models separately for their ability to predict long-term MeHg changes in sediment, sediment porewater, surface water (including suspended particulates), and dissolved-in-surface water after the creation of shallow water habitat, relative to a "no-action" scenario at the site.

\section{SUBJECT TERMS}

Duluth-Superior Harbor, Habitat Restoration, HERMES, Mercury, Screening Models, SERAFM, WASP, Duluth (Minn.) - Harbor, Superior (Wis.) - Harbor, Dredging spoil, Contaminated sediments, Methylmercury, Aquatic plants--Effect of sediments on Estuarine restoration, Environmental sciences--Mathematical models

\begin{tabular}{|c|c|c|c|c|c|}
\hline \multicolumn{3}{|c|}{ 16. SECURITY CLASSIFICATION OF: } & \multirow{3}{*}{$\begin{array}{l}\text { 17. LIMITATION OF } \\
\text { ABSTRACT } \\
\text { SAR }\end{array}$} & \multirow{3}{*}{$\begin{array}{l}\text { 18. NUMBER OF } \\
\text { PAGES } \\
57\end{array}$} & \multirow[t]{2}{*}{ 19a. NAME OF RESPONSIBLE PERSON } \\
\hline a. REPORT & b. ABSTRACT & c. THIS PAGE & & & \\
\hline & & & & & 19b. TELEPHONE NUMBER (Include area code) \\
\hline
\end{tabular}

